\title{
The Impacts of COVID-19 on the Research Enterprise
}

\section{A Landscape Review}

Jane Radecki

Roger C. Schonfeld 


\section{ITHAKA S+R}

Ithaka S+R provides research and strategic guidance to help the academic and cultural communities serve the public good and navigate economic, demographic, and technological change. Ithaka $\mathrm{S}+\mathrm{R}$ is part of ITHAKA, a not-for-profit organization that works to advance and preserve knowledge and to improve teaching and learning through the use of digital technologies. Artstor, JSTOR, and Portico are also part of ITHAKA.

Copyright 2020 ITHAKA. This work is licensed under a Creative Commons Attribution 4.0 International License. To view a copy of the license, please see https:// creativecommons.org/licenses/by/4.0/.

ITHAKA is interested in disseminating this brief as widely as possible. Please contact us with any questions about using the report: research@ithaka.org.

We thank Springer Nature for their sponsorship of this report. 


\section{Table of Contents}

$\begin{array}{ll}\text { Executive Summary } & 3\end{array}$

$\begin{array}{lr}\text { Introduction } & 4\end{array}$

Financial Impacts for Universities $\quad 4$

Revenue Sources, Excluding Funded Research $\quad 6$

Federal Research Funding $\quad 8$

Other Major Sources of Research Funding 13

Implications $\quad 14$

The Impact on Scientific Research Activities $\quad 16$

Research Disruptions $\quad 16$

Essential Research $\quad 19$

Research Collaboration $\quad 20$

Scholarly Communication $\quad 22$

Re-openings of Labs and Ramping up Research $\quad 24$

Human Impacts $\quad 26$

$\begin{array}{ll}\text { Jobs and Careers } & 26\end{array}$

Gender Disparities $\quad 28$

Graduate Students $\quad 29$

$\begin{array}{ll}\text { International Students } & 31\end{array}$

$\begin{array}{lr}\text { Conclusion } & 34\end{array}$ 


\section{Executive Summary}

The COVID-19 pandemic and associated disruptions have had a major impact on the US academic research enterprise. This report provides a landscape review of what is known about these impacts, from March through mid-October 2020, with an aim of identifying gaps that should be addressed. Our focus is on externally funded research, and therefore we emphasize STEM fields almost exclusively. As a result, we also focus on the largest research universities, which conduct an outsized share of this research and which are themselves quite reliant on the intellectual activity and revenues associated with it.

\section{Our key findings include:}

- The federal government provided substantial flexibility to universities in utilizing research funding at the beginning of the pandemic. In addition, there is little reason to anticipate substantial budget reductions among most major research funders. As a result of these factors, while universities face substantial declines to some revenue sources and risks to most others, externally funded scientific research is likely to be relatively stable. That said, the ways in which the academic research enterprise is interwoven with, and in some cases cross-subsidized by, instructional activities pose some risk to research support. There are substantial unanswered questions about how negative impacts to the business models of research universities will affect scientific research.

- Many traditional research activities were largely suspended in the spring into summer, other than COVID-19-related and other essential research. With federal flexibilities ending, universities scrambled to put in place necessary protections to allow laboratories and other research groups to safely resume their activities. Many but not all research activities have successfully restarted, even if not all are at full capacity. In parallel, the COVID-19 emergency led to substantial innovation in research collaboration and scholarly communication. It also demonstrated the limits of collaboration and communication infrastructure and services in the face of widespread attention to scientific progress and its politicization. There are substantial unanswered questions about the resiliency of the research enterprise and the permanence of the many adaptations to collaboration and scholarly communication that we have seen.

- The human impacts of the disruptions are vast. These include limitations and impediments facing international students and disruptions to researchers that differ by gender, caregiver status, and career level. There are substantial unanswered questions about international talent flows, the development of early career researchers, and setbacks in achieving gender equity.

As we write, the research enterprise is coming back to life after an unplanned and unprecedented stoppage. Given the uncertain nature of how the pandemic will proceed and what societal, economic, and educational changes will result, we expect other impacts to develop over the coming months and years. 


\section{Introduction}

COVID-19 has yielded unprecedented challenges to higher education, and observers have understandably focused on the profound disruption to traditional on-campus residential housing and face-to-face instruction. Academic research has also faced substantial disruption, with laboratories being shuttered and fieldwork largely suspended, and Ithaka S+R is in the midst of several projects to examine the research enterprise in this unprecedented year. In this landscape review, we assess what is known about the impacts of COVID-19 on STEM researchers and the STEM research enterprise at major US research universities, ${ }^{1}$ with the objective of identifying what else we need to know in order to understand impacts and craft policy and action.

\section{Financial Impacts for Universities}

The last several years have been quite turbulent for US college and university finances. Institutions have seen undergraduate enrollments decline, ${ }^{2}$ even as many institutions are finding themselves increasingly dependent on tuition and student fees as state appropriations for higher education have significantly declined over time. ${ }^{3}$ COVID-19's disruptions to traditional instructional models, to international students, and to the economy are all producing additional shortfalls for universities.

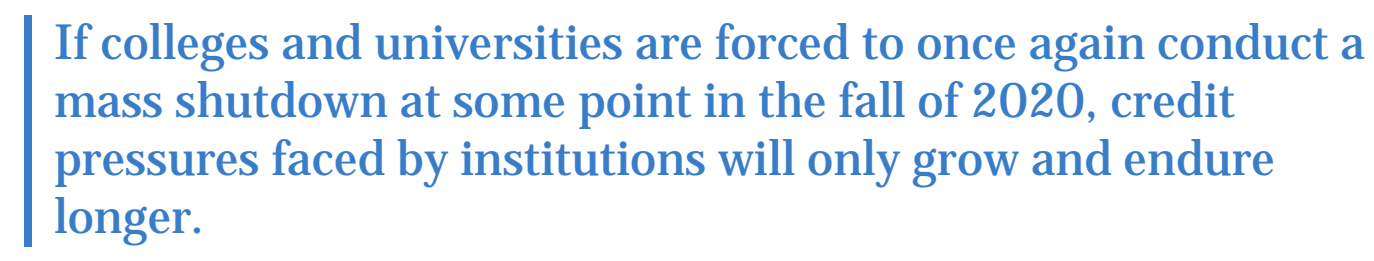

Colleges were some of the first entities in the US to completely shut down operations when Coronavirus began to spread across the country. And on March 18, 2020, Moody's downgraded the higher education sector's bond rating from stable to negative:

The outlook for the higher education sector is changing to negative from stable, reflecting both the immediate negative financial impact of the Coronavirus outbreak as well as other significant downside risks. While the duration and full financial impact of the current crisis is unknown, universities' response to the outbreak will immediately reduce revenue and drive expenses higher. For fiscal 2021, universities face

\footnotetext{
${ }^{1}$ The purpose of this report is to look at the impact of COVID-19 on researchers and the research enterprise. By research enterprise in this report we mean the facilities, business, and administrative apparatus that supports funded research as well as the sum of all the funded research projects.

${ }^{2}$ Rick Seltzer, "Tuition Revenue Growth Expected to Slow," Inside Higher Ed, November 12, 2019, https://www.insidehighered.com/quicktakes/2019/11/12/tuition-revenue-growth-expected-slow.

${ }^{3}$ Nick Hazelrigg, "The Impact of State Cuts," Inside Higher Ed, June 18, 2019, https://www.insidehighered.com/news/2019/06/18/study-finds-falling-appropriations-will-negatively-affect-degrees-awarded-public.
} 
unprecedented enrollment uncertainty, risks to multiple revenue streams, and potential material erosion in their balance sheets." 4

In April, 2020, the S\&P Global Ratings revised 84 private universities' credit ratings from stable to negative and 33 public universities' credit ratings from stable to negative. ${ }^{5}$ The reason for the change was the heightened risks associated with the financial toll of COVID-19 and the related economic recession. These relatively newly assigned negative outlooks reflect the S\&Ps "view that there is at least a one-in-three chance that operating and economic conditions will worsen to a degree that affects the ability of the college or university to maintain credit characteristics in line with the current rating." 6 If colleges and universities are forced to once again conduct a mass shutdown at some point in the fall of 2020, credit pressures faced by institutions will only grow and endure longer. While many large research institutions have strong reserves and the wiggle room to absorb some of the financial impacts, as well as relatively low debt levels, some will face continued economic and financial pressures if the dangers posed by the virus do not dissipate.

\section{Thus far, externally funded research remains a strong revenue source, with no immediate risks to its continuation.}

The five most important sources of revenue that make up the operating budget at universities include: (1) tuition and fees, (2) hospitals and healthcare, (3) grants-much of which is for externally funded research, (4) state appropriations, and (5) endowment spending. Due to the impacts of the pandemic, most of these revenue streams are at risk. Thus far, externally funded research remains a strong revenue source, with no immediate risks to its continuation. At the present all of the other major revenue sources seem to be at significant risk, but at a high level the research enterprise seems to remain in relatively good health, financially speaking.

\footnotetext{
${ }^{4}$ Michael Osborn, Susan I. Fitzgerald, and Kendra M. Smith, "Higher Education - US: Outlook Shifts to Negative as Coronavirus Outbreak Increases Downside Risks," Outlook, U.S. Public Finance (Moody's Investor Service, March 18, 2020), https://www.moodys.com/researchdocumentcontentpage.aspx?docid=PBC 1219266.

${ }^{5}$ Jessica L. Wood et al., "Outlooks Revised On Certain U.S. Not-For-Profit Higher Education Institutions Due To COVID-19 Impact," S\&P Global Ratings, April 30, 2020, https://www.spglobal.com/ratings/en/research/articles/200430-outlooks-revised-on-certain-u-snot-for-profit-higher-education-institutions-due-to-covid-19-impact-11469520.

${ }^{6}$ Ibid.
} 


\section{Revenue Sources, Excluding Funded Research}

Several potential revenue sources for research universities are being negatively affected by COVID-19.

Revenue for hospitals and healthcare providers has been severely impacted due to the cancellation of all elective surgical procedures and the reduction in provider visits during the immediate months after the virus outbreak. ${ }^{7}$ For large research universities that own their hospitals and/ or health care systems, the healthcare losses are the universities' responsibility (just as the surpluses would have been to their benefit). While some universities with medical schools limited their liability by putting hospitals and healthcare in a separate not-for-profit organization, ${ }^{8}$ in those cases where they retained responsibility, the shortfall this spring grew rapidly_in some cases to well over \$100 million for a single university hospital. While government assistance may help to compensate for a good deal of these losses, hospitals have proven to be a substantial drain on the universities that own them. ${ }^{9}$

Typically, in a recession, enrollment at colleges and universities increases as the newly unemployed decide to go back to school. However, this has not been true to date for the current COVID-19 recession. Enrollments appear to have dropped this academic year, especially for community colleges. ${ }^{10}$ Enrollments from international students, who tend to pay more tuition,

\footnotetext{
${ }^{7}$ Along with changing the rating for the higher education sector on March 20, 2020, Moody's Investor Services also downgraded the outlook for US for-profit hospitals from stable to negative stating that "earnings will decline over the next 12 to 18 months as caring for patients infected with the Coronavirus increases costs and reduces profitability." (Jonathan Kanarek and Jessica Gladstone, "Moody's - Outlook for US For-Profit Hospitals Changed to Negative On Coronavirus Outbreak," Research Announcement (New York: Moody's Investor Service, March 20, 2020), https://www.moodys.com/research/Moodys-Outlook-for-US-for-profit-hospitalschanged-to-negative--PBC 1220272). Also in March Moody's changed the outlook for nonprofit hospitals from stable to negative, once again citing declining revenues, but also loss of elective surgeries and large increased costs to prepare for COVID-19 patients. (Emma Whitford, "Pandemic Hits Academic Hospitals Hard," Inside Higher Ed, May 4, 2020, https://www.insidehighered.com/news/2020/05/04/university-affiliated-hospitals-suffer-huge-revenue-losses).

${ }^{8}$ For example, Stanford and the University of Michigan both have a medical school and own a hospital, while others such as Johns Hopkins and Yale University have a medical school but maintain external arrangements with hospitals not under the university system and separate from its balance sheet.

${ }^{9}$ The University of Michigan is an outstanding example of this landscape described. At University of Michigan and Michigan Medicine - an entity directly under the university - the postponement of elective surgeries, and caring for COVID-19 patients, is causing multi-million dollar losses. In a three-month period, the University of Michigan Health System (UMHS), or Michigan Medicine, delayed more than 14,000 surgeries and by the end of March had lost $\$ 45$ million; they were losing $\$ 4$ million a day caring for patients and ramping down all other operations. That amounted to an actual year-end loss of $\$ 139$ million. (University of Michigan Board of Regents, "Board of Regents June 25, 2020 Meeting Minutes," Meeting Minutes (Ann Arbor, Michigan: University of Michigan, June 25, 2020), https://regents.umich.edu/files/meetings/07-20/2020-07-I-1.pdf). While the university was able to receive $\$ 136$ million in government assistance to help offset their losses-along with their increased efforts to reschedule surgeries and catch up on delayed appointments and procedures_that still left them with a resulting \$3 million loss for FY 2020. (Mary Masson, "Michigan Medicine's Clinical Operations Expect Negative Financial Performance For Fiscal Year 2020," Michigan Medicine, June 29, 2020, https://www.uofmhealth.org/news/archive/202006/michigan-medicine\%E2\%80\%99s-clinical-operationsexpect-negative). Dave Spahlinger, the president of UM hospitals and health centers at University of Michigan Medical Group, stated the university hospital system took on and "accepted more than 300 COVID-19 transfer patients regardless of the cost" (Masson) and yet with a low number, relatively speaking, of COVID-19 patients cared for and elective surgeries canceled they still lost hundreds of millions. Now, imagine a university hospital, like Michigan that is under the university, that had even more COVID19 patients and one can begin to see how much a hospital can potentially affect, and at times like these, hurt a university's financial situation.

${ }^{10}$ National Student Clearinghouse Research Center, "Stay Informed with the Latest Enrollment Information: National Student Clearinghouse Research Center's Monthly Update on Higher Education Enrollment," National Student Clearinghouse Research Center, October 15, 2020, https://nscresearchcenter.org/stay-informed/.
} 
have declined most sharply, and there has been a significant decline in first year students with 16.1 percent fewer enrolling this fall as compared to $2019 .{ }^{11}$ In addition, given the unemployment rate and market turmoil, net tuition per student may have declined at some institutions as well. These factors are combining to reduce tuition revenue at many institutions.

There were also refunds of auxiliary fees in the disrupted spring semester and some drops in auxiliary fees over the summer and this fall. ${ }^{12}$ As one journalist noted, "The financial impact on institutions from the loss of auxiliary revenue from housing and dining fees, and parking fees; as well as revenues from athletics, theater, and other events, is material for many."13 As refunds of any kind are unplanned, ${ }^{14}$ they have the potential to leave a hole in operating revenue. ${ }^{15}$ In a survey conducted by NACUBO in August, decreased housing and other auxiliary revenue topped the list of other factors that are impacting the 2021 fiscal year budgets of colleges and universities. ${ }^{16}$

\footnotetext{
${ }^{11}$ National Student Clearinghouse Research Center, "Stay Informed with the Latest Enrollment Information: National Student Clearinghouse Research Center's Monthly Update on Higher Education Enrollment," National Student Clearinghouse Research Center, October 15, 2020, https://nscresearchcenter.org/stay-informed/; Madeline St. Amour, "Report: Enrollment Continues to Trend Downward," Inside Higher Ed, October 15, 2020, https://www.insidehighered.com/news/2020/10/15/worrying-enrollmenttrends-continue-clearinghouse-report-shows; Shawn Hubler, "Freshman Enrollment Drops Significantly at U.S. Universities and Community Colleges," The New York Times, October 15, 2020, https://www.nytimes.com/2020/10/15/world/freshman-enrollmentdrops-significantly-at-us-universities-and-community-colleges.html.

${ }^{12}$ In a report put out at the end of March, the University of Wisconsin-Madison announced that they were anticipating $\$ 100$ million in losses due to COVID-19, and the entire University of Wisconsin system expected to spend at least $\$ 78$ million of that on room and board refunds (Kelly Meyerhofer, "UW-Madison Braces for Estimated \$100 Million Loss Because of COVID-19 Pandemic," Wisconsin State Journal, March 31, 2020, https://madison.com/wsj/news/local/education/university/uw-madison-braces-forestimated-million-loss-because-of-covid/article fc8f7e42-cbb3-5d2d-ad16-6e1e5aab8e3a.html).

${ }^{13}$ Rick Seltzer, "S\&P Slashes Outlook for 127 Colleges," Inside Higher Ed, May 1, 2020, https://www.insidehighered.com/quicktakes/2020/05/01/sp-slashes-outlook-127-colleges.

${ }^{14}$ In light of the toll that refunds took on college and university budgets across the country many universities, such as the University of South Florida (USF), have decided to include an addendum in their housing contracts for the 2020 fall semester. This addendum specifically says that if the university is forced to shut down again this fall, due to COVID-19, students should not expect to be reimbursed in any way for housing or dining fees if they have already signed the housing contract and paid for both housing and dining (University of South Florida Housing \& Residential Education, "2020-21 USF Student Housing Agreement Addendum," Addendum (University of South Florida, June 10, 2020), https://www.usf.edu/housing/documents/2020-2021-student-housingagreement-addendum.pdf). The University of Maryland at College Park followed suit and also added an addendum paragraph to their housing contract. This paragraph states that if they have to shut dorms down once again in the fall of 2020 for the health and safety of the campus "the University shall not be obligated to issue refunds or credits, whether partial or full, for such interruptions of adjustments." (University of Maryland, "Fall 2020 Housing: Housing Addendum," Department of Residential Life, 2020, http://reslife.umd.edu/fall2020/addendum/).

15 "Room and board is a sizable chunk of what students pay each semester, and the fees are often excluded from scholarship calculations. The College Board report states that students at public four-year universities paying in-state tuition spend on average 43 percent of their budgets on room and board fees. For out-of-state students, room and board makes up 27 percent of budgets, and for students at private four-year colleges, 24 percent of budgets are room and board fees," (Emma Whitford, "Coronavirus Closures Pose Refund Quandary," Inside Higher Ed, March 13, 2020, https://www.insidehighered.com/news/2020/03/13/studentsmay-want-room-and-board-back-after-coronavirus-closures-refunds-would-take).

${ }^{16}$ Ken Redd, "Flash Poll Results: Fall 2020 Institutional Plans," National Association of College and University Business Officers (NACUBO), August 14, 2020, https://www.nacubo.org/Research/2020/COVID-19\%20Research/August\%2010\%20Flash\%20Poll.
} 
WHAT WE DON'T KNOW: How will university hospitals recover financially? If there is a second wave the COVID-19 outbreak, will they suffer further financially? How are enrollment patterns developing this fall? How much revenue will be lost in tuition and fees due to changes in enrollment? Will additional campuses be forced to shut down again?

\section{Federal Research Funding}

Large research universities, specifically in the scientific disciplines, heavily rely on external funds from government agencies such as the NIH and NSF to make their research possible. This reliance on external funds has been affected by the global pandemic, and we are seeing more money being poured into COVID-19 research, but less information provided about what is happening to non-COVID-19 related research.

\section{US universities receive a large amount of their research funding from the federal government, and in essence the federal government is the largest supporter of sponsored research.}

US universities receive a large amount of their research funding from the federal government, and in essence the federal government is the largest supporter of sponsored research. In 2018 the federal government provided "roughly 53\%, or $\$ 42$ billion, of the $\$ 79$ billion worth of research done on U.S. campuses."17 In fact, in an interview in J uly 2020, Sethuraman Panchanathan, the new director of the National Science Foundation (NSF), stated that "much of what we [NSF] do is focused on academic research—of our $\$ 7.8$ billion in funding [or obligations] for research and education, $\$ 6.1$ billion of it goes to academic institutions. For academic research, the federal government is still the majority funder - in fact, it's still the largest funder by far."18 Research conducted at universities is a vital foundational building block for the nation's further research and development (R\&D). A report published in 2011 found that "while U.S. universities perform just 13 percent of total national R\&D, they perform 31 percent of the nation's total research—basic and applied - and 56 percent of the nation's basic research."19 It is because there is broad consensus that research conducted at US universities is absolutely vital, and a long-term national investment in the future, that the federal government supports over 50 percent of the research conducted at universities. The remaining external support usually comes from industry, non-government grants, foundations, university funding, charitable foundations, nonprofits, and state and local governments.

\footnotetext{
${ }_{17}$ Jeffrey Mervis, "As Pandemic Pounds U.S. Universities, Federal Support Helps Their Labs Stay Afloat," Science, June 5, 2020, https://doi.org/10.1126/science.abd1841.

${ }^{18}$ Sriram Lakshman, "U.S. Will Continue to Lead the World in Scientific Investment and Innovation," The Hindu, July 21, 2020, https://www.thehindu.com/news/international/us-will-continue-to-lead-the-world-in-scientific-investment-andinnovation/article32153888.ece.

${ }^{19}$ Association of American Universities, "University Research: The Role of Federal Funding," January 2011, https://files.eric.ed.gov/fulltext/ED517263.pdf.
} 
Since the pandemic, federal appropriations for funded research have grown. ${ }^{20}$ In early March the first COVID-19 relief bill was passed. Since then, Congress has further provided roughly \$3.6 billion in appropriations for the National Institutes of Health (NIH) for COVID-19 research and testing; some of this money is flowing directly to university laboratories. ${ }^{21}$ This includes \$846 million in H.R.6074 - Coronavirus Preparedness and Response Supplemental Appropriations Act, 22 which primarily was for the National Institute of Allergy and Infectious Diseases, and $\$ 945$ million in H.R.748 - CARES Act, ${ }^{23}$ which was for a variety of institutes and centers. It is possible that additional pandemic-essential or stimulus funding will be appropriated to funded research activities. Furthermore, some in Congress are pushing for increased funding, and funding flexibility, for scientific research. ${ }^{24}$

Federal agencies' machinery for awarding grants has been very minimally affected. Michael Lauer, the director of the Office of Extramural Research at the NIH, stated "we went to 100\% virtual peer review [of grant proposals] practically overnight, and it's gone remarkably well."25 This is evidenced by substantial funding appropriated to COVID-19 related research. ${ }^{26}$ The NIH "provides about two-thirds of all federal funding for academic research," 27 so the state of its

\footnotetext{
20 Jeffrey Mervis, "As Pandemic Pounds U.S. Universities, Federal Support Helps Their Labs Stay Afloat," Science, June 5, 2020, https://doi.org/10.1126/science.abd1841.

${ }^{21}$ Ross A. Frommer, "Update on NIH Funding For COVID Research," Columbia University Herbert Irving Comprehensive Cancer Center, 2020, https://cancer.columbia.edu/update-nih-funding-covid-research.

${ }^{22}$ Representative Nita M. Lowery, "H.R.6074 Coronavirus Preparedness and Response Supplemental Appropriations Act," Pub. L. No. H.R.6074, Public Law: 116-123 145 (2020), https://www.congress.gov/116/plaws/publ123/PLAW-116publ123.pdf.

${ }^{23}$ Representative Joe Courtney, "H.R.748 - CARES Act," Pub. L. No. H.R.748, Public Law No: 116-136 (2020), https://www.congress.gov/bill/116th-congress/house-bill/748.

${ }^{24}$ Representative Diana DeGette et al., "H.R.7308 / S.4286 - Research Investment to Secure the Economy (RISE) Act," Pub. L. No. H.R.7308/S.4286 (2020), https://www.congress.gov/bill/116th-congress/house-bill/7308/text. This bill recommends that nearly $\$ 25$ billion be allocated to federal science agencies, $\$ 10$ billion (or 40 percent) to the NIH and $\$ 3$ billion (or 12 percent) to NSF. Additionally, if passed the following provisions would be set in place by this bill: (1) funds would be allowed to be used to enable graduate students, postdoc researchers, and PIs to complete work that has been disrupted by COVID-19, (2) funds would be allowed to be used to replace certain lab equipment, to reconfigure laboratories so that they can safely resume research under new social distancing and safety protocols, and to cover increased construction costs resulting from the disruption from COVID-19, (3) authorizes grant to be issued supporting research on the behavioral, social, or economic effects of COVID-19 and responses to the disease, and (4) this bill would extend grant flexibilities first offered in two memoranda (OMB M-20-11 and OMB M-20-17) by the $\mathrm{OMB}$ in March until labs can safely reopen. (American Institute of Physics, "Research Investment to Secure the Economy (RISE) Act - H.R.7308/S.4286," American Institute of Physics (AIP), June 24, 2020, https://www.aip.org/fyi/federal-science-bill-

tracker/116th/research-investment-secure-economy-act). The sponsors of this bill hope that by pushing this legislation forward it will help build support for including research relief in Congress' next pandemic relief response package. To date, no proposal has included research relief amounts even close to the sum that is envisioned in the RISE Act. For information and the amount of financial relief allocated to agencies see the following federal science budget tracker on COVID-19: American Institute of Physics, "Federal Science Budget," American Institute of Physics (AIP), 2020, https://www.aip.org/fyi/federal-science-budget-tracker\#covid19; Adria Schwarber, "Universities Make Case for Pandemic Relief Funds," American Institute of Physics (AIP), September 18, 2020, https://www.aip.org/fyi/2020/universities-make-case-pandemic-relief-funds.

${ }^{25}$ Jeffrey Mervis, "As Pandemic Pounds U.S. Universities, Federal Support Helps Their Labs Stay Afloat," Science, June 5, 2020, https://doi.org/10.1126/science.abd1841.

${ }^{26}$ Between existing authorities and new research appropriations, the NIH has awarded at least 455 grants related to COVID-19, totaling over $\$ 1$ billion, as of October 19,2020 . Of these, at least 310 of them, totaling over $\$ 433$ million, went to universities. TAGGS, "HHS COVID-19 Awards," TAGGS, 2020, https://taggs. hhs.gov/Coronavirus.

27 Jeffrey Mervis, "As Pandemic Pounds U.S. Universities, Federal Support Helps Their Labs Stay Afloat," Science, June 5, 2020, sec. Education, Funding, Coronavirus, https://doi.org/10.1126/science.abd1841.
} 
operations during a period of crisis driven by the global pandemic is vitally important to the university research community.

With most federal funding unimpeded, and if anything apparently growing, the bottom line for the research budget at most universities is placing many research administrators in an enviable position. Chris Cramer, who oversees the University of Minnesota's $\$ 870$ million portfolio of sponsored research said that "these days, I'm the only one who gets to say that, even with large error bars, none of my projected numbers are in the red."28

The Office of Management and Budget (OMB) issued several key memoranda that helped ensure the continuity of the federally funded portion of the research enterprise during the disruptions caused by COVID-19. ${ }^{29}$ The short term flexibility that specifically four memos provided was incredibly beneficial to university researchers, but it is important to note that there were caveats within each memo and more importantly that all of the provisions and allowances-except for one item in the most recently released memo-in these four memos have now been rescinded as of September 30, 2020.30

\footnotetext{
${ }^{28}$ In many institutions externally funded research is the only revenue stream that is holding steady and in some cases actually increasing - as Chris Cramer found when looking at his third quarter numbers at the University of Minnesota, which are "actually $\$ 2$ million ahead of last year" in terms of sponsored research (Jeffrey Mervis, "As Pandemic Pounds U.S. Universities, Federal Support Helps Their Labs Stay Afloat," Science, June 5, 2020, https://doi.org/10.1126/science.abd1841). Furthermore, the president of Johns Hopkins University, who leads the nation in the amount it spends on sponsored research, which is some $\$ 2.5$ billion annually, in a letter written in April to the Johns Hopkins community detailed that income was projected to dip by more than $\$ 100$ million for the fiscal year that ended on June 30, 2020. The letter further detailed that next fiscal year's (though June 2021) revenue shortfall could total in excess more than $\$ 475$ million. It is important to note that more than half of the projected drop in revenue comes from the loss of possibly up to $\$ 300$ million, or more, from the John Hopkins' vast network of hospitals and clinics. However, his analysis suggests the impact on sponsored research will be comparatively significantly small, further providing evidence that externally funded research is one of the only revenue streams that is not being negatively or even severely negatively impacted by COVID-19 (Ronald J. Daniels, "Financial Implications + Planning A Message from Johns Hopkins University President Ronald J. Daniels," HUB, April 21, 2020, https://hub.jhu.edu/novel-coronavirus-information/financial-implications-and-planning/). Although some institutions have been less transparent in describing how research at their university may be affected.

${ }^{29}$ More specifically there have been four memos issued by the OMB that pertain to federally funded research and have provided various forms of aid in different ways. These four memos issued are as follows: (1) OMB M-20-11, Administrative Relief for Recipients and Applicants of Federal Financial Assistance Directly Impacted by the Novel Coronavirus (COVID-19) (Margaret Weichert, "OMB M-20-11," Memorandum (Washington, D.C.: Executive Office of the President Office of Management and Budget, March 9, 2020), https://www.whitehouse.gov/wp-content/uploads/2020/03/M-20-11.pdf); (2) OMB M-20-17, Administrative Relief for Recipients and Applicants of Federal Financial Assistance Directly Impacted by the Novel Coronavirus (COVID-19) due to Loss of Operations (Margaret Weichert, "OMB M-20-17," Memorandum (Washington, D.C.: Executive Office of the President Office of Management and Budget, March 19, 2020), https://www.whitehouse.gov/wp-content/uploads/2020/03/M-20-17.pdf); (3) OMB M-2020, Repurposing Existing Federal Financial Assistance Programs and Awards to Support the Emergency Response to the Novel Coronavirus (COVID-19) (Michael Rigas, "OMB M-20-20," Memorandum (Washington, D.C.: Executive Office of the President Office of Management and Budget, April 9, 2020), https://www.whitehouse.gov/wp-content/uploads/2020/04/M-20-20.pdf); and (4) OMB M20-26 Extension of Administrative Relief for Recipients and Applicants of Federal Financial Assistance Directly Impacted by the Novel Coronavirus (COVID-19) due to Loss of Operations (Michael Rigas, "OMB M-20-26," Memorandum (Washington, D.C.: Executive Office of the President Office of Management and Budget, June 18, 2020), https://www.whitehouse.gov/wpcontent/uploads/2020/06/M-20-26.pdf).

${ }^{30} \mathrm{M}-20-17$ and $\mathrm{M}-20-20$ were both rescinded as of June 16,2020 . This means the flexibilities provided in these two memoranda have now expired and were only valid from March 16 - June 16, 2020. The flexibilities extended in M-20-11 expired on July 26, 2020. M-20-26 provided the extension of item 1, the allowability of salaries and other project activities, until September 30, 2020, at which time the extension expired. Item 2 in $M-20-26$, the extension of single audit submission, remains extended through December 31, 2020.
} 
While the scope of some memos were narrowly crafted, they did provide flexibility and "administrative relief for recipients and applicants of federal financial assistance directly impacted by the novel Coronavirus (COVID-19) due to loss of operations." 31 This includes extensions to expiring awards, ${ }^{32}$ covering benefits, allowing other project activities to be charged to awards, ${ }^{33}$ as well as incorporating the ability to charge costs that under normal circumstances would not be allowed ${ }^{34}$ _such as fees for canceling events and travel, or research activities that had to be paused and resumed at a later date due to the shutdown of laboratories. Recipients of NSF grants also had the opportunity to apply for no-cost extensions to their grants. The NIH also granted administration flexibility. These accommodations allowed institutions to continue to provide stipend payments to fellows and trainees who were unable to work as a result of the pandemic shutdown. Additionally, the NIH worked with the OMB and the Department of Health and Human Services (HHS) to identify short-term administrative flexibilities to assist those with awards during the deemed public emergency. ${ }^{35}$

The federal funding agencies, through the OMB memos, extended a decent amount of flexibility to researchers with awards. As a result, scientists who are supported by federally awarded grants have been able to draw their salary from these awards, even as many research tasks, for example those requiring laboratory access, could not be performed. The universities could continue to draw indirect costs commensurately.

The challenge now, which COGR stated in a J uly document titled "Funding Sources for Research Universities", is that "as funding sources have been exhausted or significantly

\footnotetext{
${ }^{31}$ Margaret Weichert, "NSF Implementation of OMB Memorandum M-20-17, Entitled 'Administrative Relief for Recipients and Applicants of Federal Financial Assistance Directly Impacted by the Novel Coronavirus (COVID-19) Due to Loss of Operations,"' Memorandum (Executive Office of the President Office of Management and Budget, March 19, 2020), https://www.nsf.gov/bfa/dias/policy/covid19/covid19 nsfombimplementation.pdf.

${ }^{32}$ OMB M-20-17 stipulated no-cost extensions on expiring awards, "to the extent permitted by law, awarding agencies may extend awards which were active as of March 31, 2020 and scheduled to expire prior or up to December 31, 2020, automatically at no cost for a period of up to twelve (12) months. This will allow time for recipient assessments, the resumption of many individual projects, and a report on program progress and financial status to agency staff. Project-specific financial and performance reports will be due 90 days following the end date of the extension. Awarding agencies will examine the need to extend other project reporting as the need arises." (Margaret Weichert, "OMB M-20-17," Memorandum (Washington, D.C.: Executive Office of the President Office of Management and Budget, March 19, 2020), https://www.whitehouse.gov/wp-content/uploads/2020/03/M-20-17.pdf).

${ }^{33} \mathrm{OMB}$ M-20-17 explicitly stated the following in regards to the allowability of salaries, benefits, and other project activities to be charged to the award: "Awarding agencies may allow recipients to continue to charge salaries and benefits to currently active Federal awards consistent with the recipients' policy of paying salaries (under unexpected or extraordinary circumstances) from all funding sources, Federal and non-Federal. Awarding agencies may allow other costs to be charged to Federal awards necessary to resume activities supported by the award, consistent with applicable Federal cost principles and the benefit to the project. Awarding agencies may also evaluate the grantee's ability to resume the project activity in the future and the appropriateness of future funding, as done under normal circumstances based on subsequent progress reports and other communications with the grantee" (Margaret Weichert, "OMB M-20-17," Memorandum (Washington, D.C.: Executive Office of the President Office of Management and Budget, March 19, 2020), https://www.whitehouse.gov/wp-content/uploads/2020/03/M-20-17.pdf).

34 "Awarding agencies may allow recipients who incur costs related to the cancellation of events, travel, or other activities necessary and reasonable for the performance of the award, or the pausing and restarting of grant funded activities due to the public health emergency, to charge these costs to their award without regard to 2 CFR § 200.403"(Margaret Weichert, "OMB M-20-17," Memorandum (Washington, D.C.: Executive Office of the President Office of Management and Budget, March 19, 2020), https://www.whitehouse.gov/wp-content/uploads/2020/03/M-20-17.pdf).

${ }^{35}$ Office of the Director, National Institutes of Health, "Guidance for Applicants Preparing Applications for the Fall 2020 Due Dates During the COVID-19 Pandemic," National Institutes of Health Office of Extramural Research, July 8, 2020, https://grants.nih.gov/grants/guide/notice-files/NOT-OD-20-122.html.
} 
diminished, institutional survival requires implementation of the difficult cost-cutting measures in conjunction with maximizing the significantly diminished funding sources. This is an existential crisis, which requires university leadership to prioritize the allocation of scarce funds and resources across multiple institutional functions." ${ }^{36}$ The last remaining COVID flexibility from OMB in federal research grant funding policy ended in September. ${ }^{37}$

The goal of these four memos was to attempt to preserve as much of the US research enterprise as possible in the face of unprecedented disruptions. However, with this flexibility also came caveats. As researchers drew down on their grants-to pay salaries or be reimbursed for canceled travel for research, meetings, conferences, and other activities-it meant that once labs reopened, these scientists would have less money to deliver the promised research. Many did not know, and in some cases still do not know, if they will receive supplemental funding for the additional months now needed to complete their projects.

\section{It is not clear whether researchers are once again conducting their projects at the expected pace and whether their funding will sustain their pre-existing project commitments.}

The OMB memos and related funder instructions made clear that the funding flexibility would not be extended indefinitely, providing universities with strong financial incentives to reopen laboratories and other research facilities as quickly as possible. Even so, while most labs have reopened in phases, they do not have the same capacity due to new safety protocols. It is not clear whether researchers are once again conducting their projects at the expected pace and whether their funding will sustain their pre-existing project commitments.

The closure of labs and lab-based scientific research activities not only impacted research progress and projects-it also added some pressures around indirect costs. Roughly 33 percent of federal grants are allocated towards indirect costs, ${ }^{38}$ which can only be recognized by the university as revenue when the associated direct costs are spent. Thus, even if salaries and benefits continued to be paid uninterrupted, as other direct expenses such as travel, equipment, or materials were unspent, there could be a commensurate slowdown in the recognition of indirect costs. At the same time, universities still had to pay for many of the expenses covered by these indirect costs, such as research support services, utilities, and so forth. These losses may have been relatively minor in many cases and only temporary regardless, but they still contributed to budget shortfalls at many institutions..$^{39}$

\footnotetext{
${ }^{36}$ COGR, "Funding Sources for Research Universities (Addendum to Finances of Research Universities - June 2014)" (Council on Governmental Relations, July 1, 2020), https://www.cogr.edu/sites/default/files/COGR Funding July1 2020.pdf.

${ }^{37}$ Michael Rigas, "OMB M-20-26," Memorandum (Washington, D.C.: Executive Office of the President Office of Management and Budget, June 18, 2020), https://www.whitehouse.gov/wp-content/uploads/2020/06/M-20-26.pdf.

${ }^{38}$ Stanford University, "Costs of Conducting Research," DoResearch, March 29, 2018, https://doresearch.stanford.edu/researchscholarship/costs-conducting-research.

39 Jeffrey Mervis, "As Pandemic Pounds U.S. Universities, Federal Support Helps Their Labs Stay Afloat," Science, June 5, 2020, https://doi.org/10.1126/science.abd1841.
} 
WHAT WE DON'T KNOW: Will federal funding for research continue to make allowances for COVID-19, especially if a second wave of infections further impacts universities? In the many cases that researchers continued to draw on their grants for salaries but without being able to conduct laboratory or field research, how will performance expectations and research agendas adapt? How will the presidential election and future budget negotiations affect future research funding levels?

\section{Other Major Sources of Research Funding}

Beyond federal sources, universities receive external research funding from industry, public charities, charitable foundations, nonprofits, and state and local governments. Some scientists whose research is not funded by the federal government are facing somewhat bleaker outcomes.

One particular concern is science that is supported by charitably funded entities that rely on public fundraising drives. To take one example, the Leukemia \& Lymphoma Society has already canceled grants that they previously awarded citing "unprecedented revenue losses caused by the COVID-19 pandemic." 40 Furthermore, while "nonprofits provide just 5\% of overall U.S. research funding, they often support small, high-risk pilot studies that later enable researchers to attract larger grants from government funders." ${ }^{41}$ Many of these grants are awarded to young researchers, helping them launch their careers. Even medium-sized nonprofits that fund scientific research don't seem to be "safe." In J une the \$724 million American Cancer Society (ACS) saw a \$200 million drop in revenue, and its chief medical officer said that if current economic and donation trends continue the ACS may have to temporarily cut research funding in half. 42

Research funded by larger foundations, such as the Gates Foundation, may not be as affected. Many foundations have taken it upon themselves to support research in this time of need. Certainly the funding from government agencies dwarfs the scale of private gifts from nonprofits, but nonprofits are able to distribute funds they receive much more quickly than some federal agencies. As a survey conducted in August of more than a hundred of Foundation Source's private non-operating foundation clients showed, 42 percent of responding institutions said that they had already increased their grant making significantly (13 percent) or modestly (29 percent) in 2020, while 48 percent reported that their level of grant making had stayed the same and only 10 percent said that it had declined. ${ }^{43}$ Looking ahead, 42 percent of the respondents reported that they expected their grant making to increase significantly (seven

\footnotetext{
${ }^{40}$ Eli Cahan, "COVID-19 Cancels Charity Galas and Walks. Science Is Paying the Price," Science, June 24, 2020, https://doi.org/10.1126/science.abd4836.

${ }^{41}$ Ibid.

${ }^{42}$ Ibid.

${ }^{43}$ It is important to note that most of Foundation Source's clients have assets totaling at or less than $\$ 50$ million, which is not that large. However, the answers that each of these foundations provided to generate the survey results can be seen as a microcosm of the broader nonprofit landscape which gives us as researchers a better insight into what is happening in the larger foundation community in regards to the ongoing COVID-19 pandemic crisis and what we may expect to see in the coming months. Foundation Source, "2020: The Year That Changed Everything - How Private Foundations Are Meeting This Moment," September 2020, https://foundationsource.com/resources/library/2020-client-survey-year-that-changed-everything/.
} 
percent) or modestly (35 percent), while only five percent expected grant making funding to decrease. The respondents who thus far have increased their grant making and funding cited several factors. Those foundations that increased the dollar amount of grant making attributed the decision predominantly to COVID-19 (79 percent) and the impact of the pandemic on nonprofits and the increased need for nonprofits ( 72 percent). ${ }^{44}$

WHAT WE DON'T KNOW: Will charitably funded entities continue to be able to fund researchers in the ways that they had prior to COVID-19? Are the program agendas of foundations changing and how will this shape research agendas in academic science?

\section{Implications}

While the stimulus bill passed in March has provided some budgetary and financial relief to colleges and universities, it is not clear what will happen in the fall semester of 2020 and beyond. We expect to see overly stressed operating budgets, the severity of which will ultimately be determined by the total loss of revenue due to the pandemic, the mode of instruction for this fall, and most certainly by 2020 enrollment figures. Colleges and universities can expect to continue to see budget shortfalls and tightening liquidity, which will only worsen the deeper and longer the pandemic lasts.

\section{Colleges and universities can expect to continue to see budget shortfalls and tightening liquidity, which will only worsen the deeper and longer the pandemic lasts.}

While we have mostly focused above on revenue dynamics, universities have seen some cost increases. These include public health measures such as testing, cleaning procedures, as well as urgent investments to support online instruction. In response to unavoidable costs, revenue reductions, and worrisome forecasts, many universities soon found themselves having to reduce other expenditures across the board in an effort to shore up their finances.

Personnel constitutes an enormous share of university budgets. By April, 2020, universities began to announce hiring freezes, often on an institution-wide basis. ${ }^{45}$ According to a crowdsourced list, more than 400 US universities and colleges had announced hiring freezes as of J uly 2020.46 With instruction shifted to remote and laboratories shut down, many universities furloughed a portion of their employees, especially those who were unable to do their job remotely, and some were ultimately laid off. In May 2020, The Chronicle of Higher Education identified 224 institutions that were associated with a furlough, layoff, or a contract nonrenewal resulting from COVID-19. At the time, at least 51,793 employees in academe were known to have

\footnotetext{
44 Ibid.

${ }^{45}$ One example from Berkeley: Carol Christ and Paul Alivisatos, "Coronavirus Response: Financial Impacts of COVID-19," Berkeley News, April 1, 2020, https://news.berkeley.edu/2020/04/01/coronavirus-response-financial-impacts-of-covid-19/.

46 "Incomplete/Unofficial/Unconfirmed List of Schools That Have Announced Hiring Freezes or Pauses, Professor Is In," Google Docs, 2020, https://docs.google.com/document/d/1KohP4xZdN8BZy1OMeXCAGagswvUOWpOws72eDKpBhl4/edit.
} 
been affected by these actions. ${ }^{47}$ The Chronicle noted the enormity of this downturn: "For context, consider that from 1990 to 2020, the largest February-to-March negative nominal change in employment in academe occurred in 2003, when 8,100 people were estimated to have left the higher-ed workforce." Another round of employee furloughs, salary cuts, and layoffs appeared to be starting up again at the end of September 2020.48

"The last eight months represent perhaps the most painful period in the history of American higher education. Colleges and universities employed 337,000 fewer people in August compared to February" 49 according to a release by the US Bureau of Labor Statistics. As Dan Bauman describes, "At no point since the bureau began keeping industry tallies in the late 1950s have colleges and universities ever shed so many employees at such an incredible rate."50

Other efforts have been made to reduce expenditures. Some universities decreased or in some cases suspended employer contributions to employee retirement accounts. Duke University announced a one-year suspension in contributions "to avoid cutting direct compensation." With conferences and other travel suspended, many institutions were able to realize substantial savings in travel and entertainment budgets; nevertheless this was not enough to offset the major losses felt in other areas of universities. Additionally, cost-share budgets that enable projects with certain funders and partners are often cut, while start-up funds for early career researchers may be at risk. Finally, many universities asked all faculty and staff members of their institution to carefully monitor expenses and hold off on any major expenditures until the financial budget picture became more clear.

These cost-cutting measures were instituted across the board at many universities, imposing challenges for research teams and for the offices that support funded research. As universities better understand their actual revenues, budget reductions will begin to be distributed in a more targeted fashion. Externally funded research will essentially be immune as by all accounts external federal agencies have seemed to be relatively financially stable.

Even so, substantial research support services-everything from academic libraries and research cores to laboratory safety and research security compliance - are funded by a combination of grant overheads and general appropriations. In this sense, the fully loaded cost of sponsored, or

\footnotetext{
${ }^{47}$ Chronicle Staff, "As COVID-19 Pummels Budgets Colleges Are Resorting to Layoffs and Furloughs. Here's the Latest," The Chronicle of Higher Education, May 13, 2020, https://www.chronicle.com/article/were-tracking-employees-laid-off-or-furloughed-bycolleges/.

${ }^{48}$ See for example, Natalia Alamdari, "University of Delaware Announces Layoffs, Other Measures as Budget Deficit Grown," Delaware Online, September 24, 2020, https://www.delawareonline.com/story/news/2020/09/24/university-delaware-announceslayoffs-budget-deficit-nears-250-million/3516189001/; Kate Murphy, "More Employees See Cuts as NC Universities Face Sharp Financial Losses Due to COVID-19," The News \& Observer, September 24, 2020, https://www.newsobserver.com/news/local/education/article245916490.html; Alyshia Korba, "IC to Cut 130 Faculty Positions Due to Low Enrollment," The Ithacan, October 8, 2020, https://theithacan.org/news/ic-to-cut-130-faculty-positions-due-to-low-enrollment/.

${ }^{49}$ Robert Kelchen, "Permanent Budget Cuts Are Coming: The Outlook for Higher Education Was Dim Even Before the Pandemic," The Chronicle of Higher Education, October 15, 2020, https://www.chronicle.com/article/permanent-budget-cuts-are-coming.

${ }^{50}$ Dan Bauman, "The Pandemic Has Pushed Hundreds of Thousands of Workers Out of Higher Education," The Chronicle of Higher Education, October 6, 2020, https://www.chronicle.com/article/how-the-pandemic-has-shrunk-higher-educations-work-force.

${ }^{51}$ Vincent E. Price, "President Price Announces New Steps to Secure Duke's Financial Future," Duke Today, May 13, 2020, https://today.duke.edu/2020/05/president-price-announces-new-steps-secure-dukes-financial-future.
} 
externally funded, research is not fully covered by grant awards. Notwithstanding what are sometimes substantial payments from funders for indirect expenditures, universities must cross-subsidize sponsored research from other sources, such as tuition and fees and auxiliary fees. As discussed above, COVID-19 has erased surpluses from these other sources, with potentially substantial implications for research support services. Cuts are already becoming clear in some areas, such as to academic libraries, with consequences to the materials and services they make available. ${ }^{52}$ And reductions are to be expected in many other areas if they have not already been determined. 53

WHAT WE DON'T KNOW: How will reductions in non-research revenue sources impact a university's ability to support key research support services, such as core facilities and academic libraries? Will reductions in research support services negatively impact some universities' ability to enable certain forms of research or successfully compete for certain forms of research funding?

\section{The Impact on Scientific Research Activities}

Even as universities began to examine the financial impacts they might face, many were confronted with substantial disruptions to individual projects and the rhythm of research. Immediately, many research teams and labs pivoted to studies (or testing) for COVID-19. Universities made urgent decisions about how to pause their nonessential scientific research enterprise to avoid the spread of COVID-19. In parallel, in a period of crisis, a number of challenges and innovations emerged in research collaboration and scholarly communication.

\section{Research Disruptions}

Scientific research was significantly impacted by the rapid shutdown and ramp-down of all nonessential and non-COVID-19 related research conducted in labs and with multiple team members. ${ }^{54}$ Michael Lauer, the top official in charge of grant awards at the NIH, said,

\footnotetext{
${ }^{52}$ Regarding libraries, see Lisa Peet, "Budgeting for the New Normal: Libraries Respond to COVID-19 Funding Constraints," Library Journal, September 24, 2020, https://www.libraryjournal.com/?detailStory=budgeting-for-the-new-normal-libraries-respond-to-covid19-funding-constraints; Lindsay McKenzie, "Libraries Brace for Budget Cuts," Inside Higher Ed, April 17, 2020, https://www.insidehighered.com/news/2020/04/17/college-librarians-prepare-looming-budget-cuts-and-journal-subscriptions-couldbe.

${ }^{53}$ Dean O. Smith, "Institutional Financial Strategies," in University Finances Accounting and Budgeting Principles for Higher Education, 387, Baltimore, MD: Johns Hopkins University Press, 2019. This has been identified as an issue in light of COVID by Mandë Holford and Ruth Morgan, "4 Ways Science Should Transform After COVID-19," World Economic Forum, June 17, 2020, https://www.weforum.org/agenda/2020/06/4-ways-science-needs-to-change-after-covid-19-coronavirus/.

${ }^{54}$ Paul Basken, "US Research Labs Closing Down for Everything but Coronavirus," The World University Rankings, March 23, 2020, https://www.timeshighereducation.com/news/us-research-labs-closing-down-everything-coronavirus\#survey-answer. To take one major example, at Harvard University they "shut down nearly all research operations by mid-March. From that point forward, only essential personnel were allowed to enter the labs. This included workers performing COVID-19 research that could have a nearterm impact and workers who needed to ensure the continuity of absolutely critical research functions." Furthermore, at Harvard, during the shutdown period research labs had only between $1 \%$ to $5 \%$ of their normal workforce. Nate Herpich, "Reopening Research Operations," The Harvard Gazette, May 15, 2020, https://news.harvard.edu/gazette/story/2020/05/how-harvard-ispreparing-to-safely-reopen-labs/.
} 
"essentially everything is being disrupted, in some way or another."55 Professors were given guidance on what to do with their courses during this time. However, directives to faculty, staff, and students about scientific research, and especially equipment-heavy lab work, was much less clear. This left thousands of researchers scrambling to figure out what to do and how to preserve and protect their research as restrictions were implemented across campuses.

There is ample evidence of widespread impacts on research activities. By April of 2020, “57\% of life scientists reported that they had lost some of their work. This is likely to result in financial consequences, as repetition of work will consume additional funding. Twenty-five percent of respondents reported at least one month and up to six months of work had been lost due to laboratory shutdown- with large differences seen between wet lab (73\%) and dry lab (31\%) researchers. At the same time, levels of self-perceived productivity dropped, where dry lab scientists were much more likely to continue carrying out their work from home as expected ( $29 \%$ of dry lab scientists, but only $10 \%$ of wet lab scientists, reported "at least $80 \%$ productivity")."56 At many major research universities, non-essential research was halted, 57 "in what amounts to an unprecedented stoppage of academic science in modern memory." 58 The pandemic caused eight out of 10 postdocs to have trouble performing experiments. ${ }^{59}$ Various adaptations to continue research were explored by labs that did not fully shut down; most common was shift work in order to keep lab animals and cell cultures alive. ${ }^{60}$

While difficult and new, some scientists appreciated the "break" from the lab as it allowed them to be able to catch up on reading and writing projects. ${ }^{61}$ This included "writing literature reviews, maintaining and updating laboratory notebooks, organizing data and back-burnered data analysis." ${ }^{2}$ Remote work also forced in-lab data sharing to a greater degree. ${ }^{63}$

\footnotetext{
${ }^{55}$ Paul Basken, "From Crisis, US Researchers See Prospect of Durable Gains," Times Higher Education, April 23, 2020, https://www.timeshighereducation.com/news/crisis-us-researchers-see-prospect-durable-gains.

${ }^{56}$ Jan O. Korbel and Oliver Stegle, "Effects of the COVID-19 Pandemic on Life Scientists," Genome Biology 21, no. 113 (May 11, 2020): 1-5, https://doi.org/10.1186/s13059-020-02031-1.

${ }^{57}$ For example, essential research included Coronavirus-related research, research support functions that are required by law, and work that relates to national security.

${ }^{58}$ Elizabeth Redden, "Empty Benches at Empty Lab Tables," Inside Higher Ed, March 30, 2020, https://www.insidehighered.com/news/2020/03/30/nonessential-research-has-halted-many-campuses.

${ }^{59}$ Chris Woolston, "Pandemic Darkens Postdocs' Work and Career Hopes," Nature, Work, 585 (September 8, 2020): 309-12, https://doi.org/10.1038/d41586-020-02548-2.

${ }^{60}$ Colleen Flaherty, "Guinea Pigs," Inside Higher Ed, June 23, 2020, https://www.insidehighered.com/news/2020/06/23/campuslabs-are-starting-open-back.

61 "Although $49 \%$ of scientists reported that their research hours have been reduced during the COVID-19 outbreak, many indicated that they are using the times of shutdown to devote more time to data analysis (43\%), manuscript or thesis writing (45\%), or developing grant applications (11\%)" (Jan O. Korbel and Oliver Stegle, "Effects of the COVID-19 Pandemic on Life Scientists," Genome Biology 21, no. 113 (May 11, 2020): 1-5, https://doi.org/10.1186/s13059-020-02031-1).

${ }^{62}$ Colleen Flaherty, "'Extraordinary Measures,"' Inside Higher Ed, March 18, 2020, https://www.insidehighered.com/news/2020/03/18/how-institutions-are-approaching-scientific-research-during-covid-19.

63 Jack Grove, "Research Intelligence: How to Run A Research Team Remotely," Times Higher Education, March 31, 2020 , https://www.timeshighereducation.com/career/research-intelligence-how-run-research-team-remotely.
} 
Many researchers were concerned about maintaining animals, cell lines, and cultures. Some scientists froze cell lines or tissue cultures in attempts to preserve months of research. ${ }^{64}$ In some cases, the PI continued to go into the lab to attend to animals and any other issues, rather than involving lab technicians or graduate students. Universities across the country grappled with how to best care for millions of mice, monkeys, and other research animals. ${ }^{65}$ Some labs had to euthanize mice colonies, 66 "to ensure both the safety of their staff and the welfare of the remaining animals in their care." 67 Many of these labs were criticized for this decision. 68

Research on human subjects faced significant disruptions as well. ${ }^{69}$ Many clinical research trials had to go through a tiered system in order to protect the health of patients, ${ }^{70}$ as some of these trials could not be put on hold. ${ }^{71}$

Unable to travel either internationally or to remote sites, many scientific researchers lost critical data and sometimes entire projects during the height of the pandemic. ${ }^{72}$ Field work disruptions lead to holes in data, especially for multi-year projects. ${ }^{73}$

${ }^{64}$ Elizabeth Redden, "Empty Benches at Empty Lab Tables," Inside Higher Ed, March 30, 2020, https://www.insidehighered.com/news/2020/03/30/nonessential-research-has-halted-many-campuses.

${ }^{65}$ David Grimm, "Respirators, Quarantines, and Worst-Case Scenarios: Lab Animal Facilities Grapple With The Pandemic," Science, March 18, 2020, https://doi.org/10.1126/science.abb7864.

${ }^{66}$ While some scientists are able to care for animals in their normal facilities while taking extra precautions and social distancing measures, and some have been able to take specimens home, others, sadly-mostly mice-have had to be euthanized. This is not an easy decision for any researcher. "One researcher at Oregon Health \& Science University in Portland has had to euthanize more than two thirds of her mice. Elsewhere in the United States, a researcher at Carnegie Mellon University reports culling 600 mice; two scientists at Harvard say they have had to kill half of their research mice; and a team at the Memorial Sloan Kettering Cancer Center has been asked to designate no more than $60 \%$ of its animals as essential" (Anna Nowogrodzki, "Cull, Release or Bring Them Home: Coronavirus Crisis Forces Hard Decisions For Lab Animals," Nature, March 30, 2020,

https://www.nature.com/articles/d41586-020-00964-y.)

${ }^{67}$ David Grimm, "'It's Heartbreaking.' Labs Are Euthanizing Thousands of Mice in Response to Coronavirus Pandemic," Science, March 23, 2020, https://doi.org/10.1126/science.abb8633.

${ }^{68}$ Marc Parry, "Colleges Euthanized Lab Animals to Protect Employees from Covid-19. Now They Face an Onslaught of Criticism," The Chronicle of Higher Education, April 10, 2020, https://www.chronicle.com/article/colleges-euthanized-lab-animals-to-protectemployees-from-covid-19-now-they-face-an-onslaught-of-criticisml.

${ }^{69}$ Marc Parry, "As Coronavirus Spreads, Universities Stall Their Research to Keep Human Subjects Safe," The Chronicle of Higher Education, March 18, 2020, https://www.chronicle.com/article/as-coronavirus-spreads-universities-stall-their-research-to-keephuman-subjects-safel.

${ }^{70}$ Kelly Servick et al., "Updated: Labs Go Quiet as Researchers Brace for Long-Term Coronavirus Disruptions," Science, March 16, 2020, https://doi.org/10.1126/science.abb7259.

${ }^{71}$ However, now research teams are contemplating the ways in which the global pandemic may have an effect, or fully insert itself, into trial results that could not be halted during this ramp-down period. "Could changes induced by the pandemic - including less consistent follow-up visits, reduced movement, poorer mental or physical health, or infection with the novel Coronavirus itself - blur the statistical signals of a treatment's risks and benefits?" (Kelly Servick, "Clinical Trials Press on for Conditions Other Than COVID19. Will the Pandemic's Effects Sneak Into Their Data?," Science, May 6, 2020, https://doi.org/10.1126/science.abc6606).

72 Jim Erickson, "COVID-19 Pandemic Disrupts U-M Research Projects Far and Wide," Michigan News, March 19, 2020, https://news.umich.edu/covid-19-pandemic-disrupts-u-m-research-projects-far-and-wide/.

${ }^{73}$ For example, the summer research season in Antarctica was suspended due to COVID-19. "Researchers often spend years preparing for an Antarctic field season, where critical data—collected at great cost—feeds into climate science, ecology, psychology, and space exploration. Scientists are sharing their alarm over what stands to be lost." "There's an unrecoverable gap that is being formed right now, and it is truly global"(Amanda Heidt, "Coronavirus Precautions Stall Antarctic Field Research," The Scientist, June 15, 2020, https://www.the-scientist.com/news-opinion/coronavirus-precautions-stall-antarctic-field-research-67636);“Regarding fieldwork, policies vary. Some institutions have shut down fieldwork entirely, while others are making some allowances. As peak 


\section{The spread of the virus has slowed scientific research and discovery and it may have altered certain projects and experiments for good.}

Equipment shared across labs, in some cases on a university-wide basis, is causing another set of issues. In certain circumstances, rather than having individual lab affiliates use that equipment, core facilities staff are doing so on their behalf. While this increases social distancing it may provide challenges in running the experiments. ${ }^{74}$ While those in core facilities may be experts at using said equipment, they are not experts on the experiments themselves, and researchers risk having samples or tests run incorrectly. The pandemic has not only been challenging at university, but also at national major research facilities that are crucial for scientific research. The burden is felt most acutely by those researchers who require physical examinations: "Most experimental research centers have closed or have transitioned to virtual operations; some are now beginning to operate at reduced levels required by social distancing. Travel restrictions and differing approaches to the pandemic are particularly challenging for international visitors to domestic facilities and for U.S. scientists visiting and working at major facilities in the U.S. and other countries." 75 The spread of the virus has slowed scientific research and discovery and it may have altered certain projects and experiments for good. "Angst over missed opportunities is widespread." ${ }^{\prime 76}$

WHAT WE DON'T KNOW: Will research and labs on campus be forced to shut down once again if there is either a resurgence of the virus or if a specific university must close? Have universities developed resilience measures to manage the research enterprise in the case of a second wave of infections or other risk scenarios? Are individual labs and research agendas planning for how to manage the risk of future suspensions?

\section{Essential Research}

Even as universities paused non-essential projects and activities, there was a huge uptick in research related to COVID-19 (and in other cases the repurposing of research laboratories to support large-scale human COVID-19 testing). Many researchers began working for the first

\footnotetext{
fieldwork season draws nearer, some projects have been allowed to continue depending upon needs and timing (e.g. losing the snow pack). Research in forestry, for example, is dependent upon a seasonal clock, and missing a measurement period can have significant ramifications for the viability of a project. In these cases, human safety is prioritized, but some institutions are granting waivers if there are ways to aid researchers without jeopardizing the health of people" (CNI, "What Happens to the Continuity and Future of the Research Enterprise?" Coalition for Networked Information, May 2020, https://www.cni.org/wpcontent/uploads/2020/05/CNI-Research-Continuity-ER-Report-s20-Public-FINAL.pdf).

${ }^{74}$ Colleen Flaherty, "Guinea Pigs," Inside Higher Ed, June 23, 2020, https://www.insidehighered.com/news/2020/06/23/campuslabs-are-starting-open-back.

${ }^{75}$ American Institute of Physics, "Peril and Promise: Impacts of the COVID-19 Pandemic on the Physical Sciences," Letter Report, American Institute of Physics (AIP), June 25, 2020, https://www.aip.org/sites/default/files/aipcorp/files/peril-and-promise-final.pdf.

${ }^{76}$ Kelly Servick et al., "Updated: Labs Go Quiet as Researchers Brace for Long-Term Coronavirus Disruptions," Science, March 16, 2020, https://doi.org/10.1126/science.abb7259.
} 
time on issues related to COVID-19, pivoting their research agendas in a crisis, and many universities celebrated this response. ${ }^{77}$

While much of this pivot has resulted in desperately needed research, some also see potential risks. For example, writing in Nature Medicine, Pai Madhukar described how "Entire fields of research are being lured away from their primary area of expertise to the pandemic response," noting an array of downsides, including the possibility that other health priorities are ignored. ${ }^{78}$ The longer term implications of this pivot remain unclear.

WHAT WE DON'T KNOW: How long will this "pivot" last and could it negatively impact other areas of research? What longer-lasting effects will we see in research agendas?

\section{Research Collaboration}

The search to better understand the Coronavirus and to find a vaccine has generated scientific research collaboration at levels that have never before been seen. COVID-19 is also eroding the secrecy that sometimes pervades academic scientific and medical research because, as The New York Times noted, "the ability to work collaboratively, setting aside your personal academic progress, is occurring right now because it's a matter of survival."79 Progress has been accelerated by the vast amount of data sharing, particularly gene sequencing data.

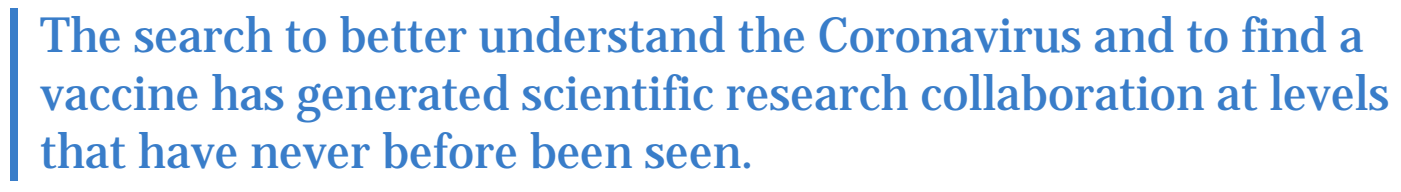

While there were similar global efforts in the fights against cancer and HIV/ AIDS, these efforts spanned decades. By contrast, university and global collaboration on COVID-19 began just three months after the virus was identified. ${ }^{80}$

\footnotetext{
77 To take just a few examples: Robert Sanders, "Scientists Pivot to COVID-19 Research, Hoping for Quick Result to Deal With Pandemic," Berkeley News, May 19, 2020, https://news.berkeley.edu/2020/05/19/scientists-pivot-to-covid-19-research-hoping-forquick-results-to-deal-with-pandemicl; Keck School of Medicine of USC, "USC Research Pivots to Meet the Coronavirus Crisis Head On," Keck School News, July 9, 2020, https://keck.usc.edu/usc-research-pivots-to-meet-the-coronavirus-crisis-head-on/. Tufts University is a noteworthy example of a large pivot across the research enterprise to attempt to aid in COVID-19 research, David Levin, "Researchers Across Tufts Pivot to Fight COVID-19," Tufts Now, June 18, 2020, https://now.tufts.edu/articles/researchersacross-tufts-pivot-fight-covid-19.

${ }^{78}$ Madhukar Pai, "Covidization of Research: What Are the Risks?," Nature Medicine 26 (July 27, 2020): 1159, https://doi.org/10.1038/s41591-020-1015-0.

${ }^{79}$ Matt Apuzzo and David D. Kirkpatrick, "COVID-19 Changed How the World Does Science, Together," The New York Times, April 14, 2020, https://www.nytimes.com/2020/04/01/world/europe/coronavirus-science-research-cooperation.html.

80 Joyce Lau, "Coronavirus Crisis Inspiring ‘Unprecedented' Global Research Effort," Times Higher Education, March 25, 2020, https://www.timeshighereducation.com/news/coronavirus-crisis-inspiring-unprecedented-global-research-effort.
} 
COVID-19 has affected almost every country in the world, creating a sense of urgency. ${ }^{81}$ The level of intense communication across countries and institutions has catalyzed unusual levels of research collaboration, allowing scientists to move faster than during any other outbreak.

This has allowed researchers to identify and share hundreds of viral genome sequences, ${ }^{82}$ and hundreds more clinical trials have been launched, bringing together labs and hospitals around the globe. ${ }^{83}$ Collaborations are also taking place at a national level, such as the National COVID19 Cohort Collaborative (N3C) ${ }^{84}$ database. ${ }^{85}$ In many ways COVID-19 is a wakeup call for better scientific research cooperation and collaboration. ${ }^{86}$ Through these collaborations, scientific researchers who otherwise may have never crossed paths are now able to discuss and brainstorm over videoconferences, share data, ideas, and findings, and work together to try and help find solutions.

\section{COVID-19, for now, has changed the way that the world
conducts scientific research together.}

A community that was once known for being secretive about their data now has a "growing sense of mission taking priority over individual credit, and the spreading realization of ways in which one field can benefit another." ${ }^{77}$ Research scientists of all fields have been forced to become not only more creative, but more cooperative and resilient. COVID-19, for now, has changed the way that the world conducts scientific research together: "While political leaders have locked their borders, scientists have been shattering theirs, creating a global collaboration unlike any in history. Never before, researchers say, have so many countries focused simultaneously on a single topic with such urgency." 88 "Collaborating in science is nothing new.

\footnotetext{
${ }^{81}$ As of October 13, 2020, 189 countries of 195 have COVID-19 cases according to the Johns Hopkins University COVID-19 tracking dashboard (Johns Hopkins University, "COVID-19 Dashboard by the Center for Systems Science and Engineering (CSSE) at Johns Hopkins University (JHU)," Johns Hopkins University \& Medicine Coronavirus Resource Center, July 7, 2020, https://coronavirus.jhu.edu/map.html).

${ }^{82}$ See for example: https://www.gisaid.org/.

${ }^{83}$ For example, "vaccine researchers at Oxford recently made use of animal-testing results shared by the National Institutes of Health's Rocky Mountain Laboratory in Montana" (Matt Apuzzo and David D. Kirkpatrick, "COVID-19 Changed How the World Does Science, Together," The New York Times, April 14, 2020, https://www.nytimes.com/2020/04/01/world/europe/coronavirus-scienceresearch-cooperation.html).

${ }^{84} \mathrm{NIH}$, "National COVID Cohort Collaborative (N3C)," NIH: National Center for Advancing Translational Sciences, September 3 , 2020, https://ncats.nih.gov/n3c.

${ }^{85}$ This effort is supported by the National Center for Advancing Translational Science (NCATS), which is a division of the NIH. This "database is collecting information from electronic health records or patients who have been tested for COVID-19-whether those tests came back positive or negative-or who have reported COVID-like symptoms. Health care providers submit the records and NCATS makes them available for any credentialed researcher to analyze" (Emma Yasinski, "Big Data Collaboration Seek to Fight COVID-19," The Scientist, July 21, 2020, https://www.the-scientist.com/news-opinion/big-data-and-collaboration-seek-to-fight-covid19-67759).

${ }^{86}$ Richard A. Roehrl, Wei Liu, and Shantanu Mukherjee, "The COVID-19 Pandemic: A Wake-Up Call for Better Cooperation at The Science-Policy-Society Interface," Policy Brief, United Nations Department of Economic and Social Affairs, April 2020, https://www.un.org/development/desa/dpad/wp-content/uploads/sites/45/publication/PB 62.pdf.

${ }^{87}$ Paul Basken, "From Crisis, US Researchers See Prospect of Durable Gains," Times Higher Education, April 23, 2020, https://www.timeshighereducation.com/news/crisis-us-researchers-see-prospect-durable-gains

${ }^{88}$ Matt Apuzzo and David D. Kirkpatrick, "COVID-19 Changed How the World Does Science, Together," The New York Times, April 14, 2020, https://www.nytimes.com/2020/04/01/world/europe/coronavirus-science-research-cooperation.html.
} 
However, as we adjust to life during a pandemic, more researchers might require support from colleagues and depend on those partnerships to collect the data they need to keep their labs operational." ${ }^{\prime 9}$ However, it is not clear whether this level of local university, national, and international collaborations will continue beyond COVID-19.

WHAT WE DON'T KNOW: Will research collaboration continue at this enhanced level and in additional fields of study? In what ways will this global pandemic be a catalyst that ends up changing research culture? Has the suspension of in-person research work-both in the laboratory and through in-person conferences-created new levels and mechanisms for communication and cooperation that might belasting?

\section{Scholarly Communication}

The systems for communicating scholarship were stressed substantially during the height of the pandemic. The pandemic provided, in real time, a master class in the opportunities and challenges of speedy open early-stage research sharing. ${ }^{90}$ The benefits of preprints, in enabling large-scale early-stage research communication, became apparent, as medRxiv and bioRxiv in particular saw a surge of submissions. ${ }^{91}$ Other scientific communication has been even less formal than preprints. ${ }^{92}$ Yet, in an environment of unrelenting public interest, and the unforeseen politicization of clinical care findings, preprint services have had to adapt rapidly, developing review systems to prevent misuse and providing disclaimers, among other changes. ${ }^{93}$ Some observers felt these shortcomings risked launching an "infodemic of bad information." ${ }^{4}$ Some medical journals also launched a fast-track peer review process that demonstrated the efficiencies that could be driven, at least under emergency conditions, into their editorial processes. Many publishers made Coronavirus and related research papers freely available, ${ }^{95}$ and some observers felt these developments were accelerating the shift towards open access. ${ }^{96}$

\footnotetext{
${ }^{89}$ Christie Sampson and Steven M. Vamosi, "Don't Let COVID Stop Your Fieldwork: Three Tips For Successful Collaborations," Nature, October 15, 2020, https://doi.org/10.1038/d41586-020-02903-3.

${ }^{90}$ See for example Lucia Loffreda, "What Does COVID-19 Mean for Scholarly Communication? Four Areas to Consider," Research Consulting, April 7, 2020, https://www.research-consulting.com/covid-19-and-scholarly-communication/.

${ }^{91}$ Ewen Callaway, "Will The Pandemic Permanently Alter Scientific Publishing?" Nature, Science After the Pandemic, 582 (June 11, 2020): 167-68, https://doi.org/10.1038/d41586-020-01520-4.

${ }^{92}$ For example, "scientists at the University of Pittsburgh discovered that a ferret exposed to COVID-19 particles had developed a high fever - a potential advance toward animal vaccine testing. Under ordinary circumstances, they [the researchers] would have started work on an academic journal article." Instead the scientist who discovered this realized that there would be plenty of time to get papers published and within two hours of learning of the ferret's fever "shared the findings with scientists around the world on a World Health Organization conference call" (Matt Apuzzo and David D. Kirkpatrick, "COVID-19 Changed How the World Does Science, Together," The New York Times, April 14, 2020, https://www.nytimes.com/2020/04/01/world/europe/coronavirus-scienceresearch-cooperation.html).

${ }^{93}$ See for example: Kai Kupferschmidt, "'A Completely New Culture of Doing Research.' Coronavirus Outbreak Changes How Scientists Communicate," Science, February 27, 2020, https://doi.org/10.1126/science.abb4761.

${ }^{94} \mathrm{Ibid}$.

${ }^{95}$ STM Publishing, "Publisher Support for Combating COVID-19," STM, 2020, https://www.stm-assoc.org/about-theindustry/coronavirus-2019-ncovl.

${ }^{96}$ Kai Kupferschmidt, '“A Completely New Culture of Doing Research.' Coronavirus Outbreak Changes How Scientists Communicate," Science, February 27, 2020, https://doi.org/10.1126/science.abb4761; "The Coronavirus (COVID-19) Outbreak Highlights Serious Deficiencies in Scholarly Communication," Research to Action the Global Guide to Research Impact, March 13, 2020, https://www.researchtoaction.org/2020/03/the-coronavirus-covid-19-outbreak-highlights-serious-deficiencies-in-scholarly-
} 
At the same time, several papers evincing research misconduct were published in top-tier journals and subsequently retracted. ${ }^{97}$ The combined effect of accelerating research communication and an endless thirst for public information about the disease led to single studies, in some cases themselves inadequate in terms of research design, driving a public narrative about potential treatments that were not thoroughly vetted. ${ }^{98}$

Beyond these elements of comparatively traditional scholarly communication, we also have seen the development of some newer companions. At early stages of the pandemic, some research teams were using tools like Slack for rapid conversations. ${ }^{99}$ And scholarly collaboration networks, including Mendeley and ResearchGate, launched focused services to enable sharing and collaboration for COVID- 19 researchers. ${ }^{100}$ We have also seen some of the benefits of social media, with one set of observers finding that "Twitter has facilitated vital counternarratives from the scientific community during....instances of controversial scientific communication." 101

There are also questions about how travel suspensions and the switch to online meetings would affect scholarly communication, with observers expressing special concern about international collaborations that have blossomed under the encouragement of policy makers and funding agencies. ${ }^{102}$ Bearing this in mind, a number of researchers have provided overviews and analyses of COVID-19 research publication patterns, including impacts on international research distribution and collaboration. ${ }^{103}$ Scholarly societies based in the US have noted that shifting their face-to-face meetings online may actually have increased participation. ${ }^{104}$ At least one

communication/. At a minimum, they accelerated publishers' efforts to integrate preprints into their workflows. Roger C. Schonfeld and Oya Rieger, "Publishers Invest in Preprints," The Scholarly Kitchen, May 27, 2020,

https://scholarlykitchen.sspnet.org/2020/05/27/publishers-invest-in-preprints/.

${ }^{97}$ Elizabeth Redden, "Rush to Publish Risks Undermining COVID-19 Research," Inside Higher Ed, June 8, 2020, https://www.insidehighered.com/news/2020/06/08/fast-pace-scientific-publishing-covid-comes-problems; Andrew Joseph, "Lancet, New England Journal Retract COVID-19 Studies, Including One That Raised Safety Concerns About Malaria Drugs," STAT News, June 4, 2020, https://www.statnews.com/2020/06/04/lancet-retracts-major-covid-19-paper-that-raised-safety-concerns-aboutmalaria-drugs/.

${ }^{98}$ Len Strazewski, "How Science Communication Is Failing During COVID-19," AMA, July 27, 2020, https://www.amaassn.org/delivering-care/public-health/how-science-communication-failing-during-covid-19.

${ }^{99}$ Kai Kupferschmidt, '“A Completely New Culture of Doing Research.' Coronavirus Outbreak Changes How Scientists Communicate," Science, February 27, 2020, https://doi.org/10.1126/science.abb4761.

${ }^{100}$ See for example this April 17 piece by ResearchGate CEO: Ijad Madisch, "How COVID-19 Is Changing Science," Scientific American, April 17, 2020, https://blogs.scientificamerican.com/observations/how-covid-19-is-changing-science/).

${ }^{101}$ Simon Pollett and Caitlin Rivers, "Social Media and the New World of Scientific Communication During the COVID-19 Pandemic," Clinical Infectious Diseases ciaa553 (May 12, 2020): 1-3, https://doi.org/10.1093/cid/ciaa553.

102 Simon Baker, "How COVID-19 Is Reshaping International Research Collaboration," Times Higher Education, August 3, 2020, sec. Coronavirus, Data, Internationalization, Research, https://www.timeshighereducation.com/news/how-covid-19-reshapinginternational-research-collaboration.

${ }^{103}$ Digital Science, Daniel Hook, and Simon Porter, "How COVID-19 Is Changing Research Culture," Digital Science, June 2020, 124, https://doi.org/10.6084/m9.figshare.12383267.v2.; Jenny J. Lee and John P. Haupt, "Scientific Globalism During a Global Crisis: Research Collaboration and Open Access Publications on COVID-19," Springer Nature, Higher Education, July 24, 2020, 1-18, https://doi.org/10.1007/s10734-020-00589-0.; Jenny J. Lee and John P. Haupt, "International Research Collaborations on COVID-19 Amidst Geopolitical Tensions with China," Research Square, June 25, 2020, 1-11, https://doi.org/10.21203/rs.3.rs-37599/v1.; Caroline V. Fry et al., "Consolidation in a Crisis: Patterns of International Collaboration in Early COVID-19 Research," PLOS ONE, July 21, 2020, 1-15, https://doi.org/10.1371/journal.pone.0236307.

${ }^{104}$ Laura Brown and Roger C. Schonfeld, "Scholarly Societies in the Age of COVID," Ithaka S+R, forthcoming. 
translational public science program saw a surge in participation, perhaps as some scientists reevaluated their priorities while research was paused. ${ }^{105}$

\section{WHAT WE DON'T KNOW:}

- How well has rapid peer review actually worked? Have editors found opportunities to drive greater efficiencies, and if so, how can they be deployed into regular editorial processes? What suffered in prioritizing speed? Will publishers develop new approaches to editorial peer review that optimize both for rigor and for speed?

- What kinds of "virtual events" will develop a lasting presence in scientific communications? Will there be a return to large-scale in-person conferences?

- Will we see an increase (even in the long-term) in scholars sharing and using data from others given individuals limitations in data collection during 2020 (and beyond)?

\section{Re-openings of Labs and Ramping up Research}

Matthew Dean, who directs graduate studies for the Molecular Biology program at the University of Southern California (USC), ${ }^{106}$ stated that lab work makes up the largest part of the program's research, so not being able to conduct any research for months has been difficult: "That's the engine of data that gives us everything - papers, grant writing, everything stems from the lab." 107

While many research labs at universities began to open back up in the summer of 2020, after being closed for all but essential research for several months, research isn't exactly back to normal. One of the biggest challenges that many labs face is how to keep their researchers physically distanced to limit any potential spread of Coronavirus. Many universities created research lab re-entry plans to be a "resource meant to establish clear and consistent guiding principles for the conduct of research in the era of COVID-19, to define operational protocols and precautions that minimize risk of viral transmission in a laboratory/ research environment, and to provide examples of how the physical and temporal space of laboratories might be organized to enact these protocols in accord with these principles."108 COVID-19 has impacted nearly every facet of the research enterprise and therefore many universities have gone through precautionary phased approaches to ramp up research activity. ${ }^{109}$ Many labs are working and staffed in shifts in order to reduce contact and all researchers and personnel are wearing masks, along with other PPE, while staying socially distanced from one another. ${ }^{110}$ This makes

\footnotetext{
${ }^{105}$ Nikki Forrester, "How The Coronavirus Pandemic Is Changing Virtual Science Communication," Nature, July 9, 2020, https://doi.org/10.1038/d41586-020-02075-0.

106 "MCB Ph.D. Program," USC Dornsife, 2020, https://dornsife.usc.edu/mcb/phdhome/.

${ }^{107}$ Grayson Schmidt, "As Labs Reopen, USC Researchers Adjust to New Campus Guidelines," USC News, July 13, 2020, https://news.usc.edu/173160/usc-research-labs-reopen-campus-guidelines-covid-19.

${ }^{108}$ Harvard University Laboratory Reopening Planning Committee, "Research Laboratory Re-Entry Plan," Office of the Provost, May 14, 2020, https://provost.harvard.edu/research-laboratory-reentry.

${ }^{109}$ Erica K. Brockmeier, "Research Returns to Campus," Penn Today, June 8, 2020, https://penntoday.upenn.edu/news/phase-iresearch-resumption.

${ }^{110}$ A lab at Princeton, like many others across the country, has divided the day into "three six-to-seven-hour shifts. This means that some members of the lab are coming in around 10 p.m. and leaving around 5 a.m." (Katie Tam, "Inside Look: Labs Reopen with
} 
collaboration difficult at times, especially when the lab is not that large to begin with squarefootage wise. 111

Modern STEM research is almost always a collaborative process, and in our current environment researchers are impeded in the informal and social engagements with their colleagues. "J ust as critical, a team member walking through the lab and noticing that a process looks wrong, or looking over the shoulder at some data and recognizing an issue, has been a normal and important part of how countless experimental researchers have learned their crafts. The opportunities for such encounters are now greatly reduced."112

Research is one of the core functions of many universities in the US, and while countless researchers are eager to get back to their research and careers are at stake, guidelines must be put in place to ensure the safety of all lab members. ${ }^{113}$ Training about COVID-19 must be completed by all lab and research personnel. In many cases researchers must pass COVID-19 screenings and complete daily health checks prior to coming into the lab for the day/ shift, occupancy limits are strictly enforced, researchers must work in their reserved or assigned time slots, labs must be extensively cleaned, and masks and PPE (gloves, disposable gowns, face shields, shoe coverings, masks, etc.) are a must at all times. ${ }^{114}$ However, as research ramps up, labs reopen, and students return to campus, institutions need to rethink training. This is especially challenging for new personnel and students who must in some cases be taught how to use complicated equipment or handle toxic and or lethal chemicals by a socially distanced mentor. Some labs have to also take into account how to protect human subjects who volunteer for studies.

Strict Social Distancing, as U. Researchers Begin 'Phased Resumption,"' The Daily Princetonian, June 24, 2020, https://www.dailyprincetonian.com/article/2020/06/princeton-phased-resumption-research-work-pandemic-coronavirus.)

${ }^{111}$ For example, at the University of Michigan "each lab/studio room can only accommodate a maximum of 1 person per 144 square feet. If you cannot maintain at least 6 feet of social distance, or the person per square feet requirement, then the schedule will need to be revised and/or reconfigured to achieve these. Small, narrow laboratories/facilities smaller than 288 square feet can only accommodate one person at a time. Lab benches are not 6 feet across, thus plan for work to occur only on one side of the lab bench in most instances" (University of Michigan Medical School Office of Research, "University of Michigan Guidelines for Safe Lab Work," University of Michigan Office of Research, May 10, 2020, https://research.medicine.umich.edu/sites/default/files/resourcedownload/u-m guidelines for safe lab work.pdf.)

112 Peter Schiffer and Jay Walsh, "Known Unknowns," Inside Higher Ed, October 13, 2020, https://www.insidehighered.com/views/2020/10/13/impact-social-distancing-process-and-outcomes-university-research-opinion.

${ }^{113}$ For example, at University of Washington, "Every principal investigator — a professor or head of a research group — must prepare a detailed plan for resuming in-person research while maintaining social distancing requirements and other safety measures. There's quite a lot that must go into this plan: strict limits on the number of people in each room in the research space; moving equipment and staggering schedules to accommodate social distancing; use of personal protective equipment; designating who will do what; educating team members about health attestation and safety requirements; and staying home if they come down with symptoms. Then, they must get that plan approved by their department chair or equivalent, order and receive all necessary supplies - including personal protective equipment - and that's all before anyone can even show up to campus" (James Urton, "UW Guidelines Helping to Ramp Up Research Safely During COVID-19," UW News. June 4, 2020, https://www.washington.edu/news/2020/06/04/research-ramp-up-covid19/?utm campaign=HQ EXLResearch 3pcurated\&utm content=131788858\&utm medium=social\&utm source=twitter\&hss chann el=tw-1078298744456732672)

114 Grayson Schmidt, "As Labs Reopen, USC Researchers Adjust to New Campus Guidelines," USC News, July 13, 2020, https://news.usc.edu/173160/usc-research-labs-reopen-campus-guidelines-covid-19. 
Still, even as many labs on campuses adjust, some researchers may struggle to return due to the new way of life in the lab. ${ }^{115}$ Even as research resumes, there's no guarantee currently that it won't be shut down again, especially if we see a spike or resurgence in the virus this fall, or universities reverse their decision to reopen, as many already have. ${ }^{116}$ Even though many labs have ramped up, many researchers are experiencing anxiety and say that they do not feel safe coming back. ${ }^{117}$ Momentum on projects has been lost, personal interactions- often vital for research work- are limited or socially distanced, and despite all the guidelines and protocols enacted, there will undoubtedly be new cases. Then again, staffing a lab at low levels under stringent protocols is much better than being shut down.

WHAT WE DON'T KNOW: Will research productivity return to normal levels under the laboratory reopening plans? What about field research?

\section{Human Impacts}

COVID has had an array of impacts on researchers, including faculty members, postdocs, technicians, and graduate students. It impacted their educational progress, their career development, their work-life balance, and their immigration status. While COVID-19 may not have caused disparities within the research enterprise, it has exacerbated pre-existing inequalities.

Pre-Cononavirus, select international undergraduate and graduate students still sometimes had difficulties obtaining visas, graduate students still had trouble finding and locking down faculty positions and funding, researchers' careers were still being impacted by numerous variables and events, and women still faced gender inequality in scientific research and the STEM fields. All of these issues have been heightened by COVID-19. These represent just some of the human impacts that COVID-19 has had, is having, and will continue to have on the research enterprise and individual researchers.

\section{Jobs and Careers}

Scientists' careers across the country are being affected in a number of ways.

J obs are in far scarcer supply than in previous years. ${ }^{118}$ Many universities have paused or cancelled job searches as a cost saving measure. ${ }^{119}$ In addition, the furloughs and job cuts

\footnotetext{
${ }^{115}$ Some individuals may have underlying health conditions that put them more at risk and therefore feel more comfortable continuing to conduct research at home while others may have young children or elders to care for that prevents them from coming into the lab during their designated shift.

${ }^{116}$ Benjamin Renton, "Reversals in Colleges' Fall 2020 Reopening Plans," Inside Higher Ed, 2020, https://www.insidehighered.com/coronavirus-colleges-reverse-reopening-plans.

${ }^{117}$ Patrick Boyle, "Academic Labs Are Opening Back Up. Still, Research Isn't Exactly Back to Normal," AAMC, July 20, 2020, https://www.aamc.org/news-insights/academic-labs-are-opening-back-still-research-isn-t-exactly-back-normal.

${ }^{118}$ Katie Langin, "Amid Pandemic, U.S. Faculty Job Openings Plummet," Science, October 6, 2020, https://doi.org/10.1126/science.caredit.abf1379.

${ }^{119}$ For example, Brown University noted "the financial consequences resulting from the increased expenditures and the dramatic reductions in revenue provoked by the current pandemic demand and prompt attention" (Richard M. Locke, "Changes to Hiring and
} 
mentioned above are more likely to affect those in contract (rather than ladder) positions, potentially putting early career researchers at greater risk.

For graduate students and early career scientists, the disruptions have made it increasingly challenging for them to complete necessary research and to advance their careers. Some of the most vulnerable individuals in this situation are early career scientists. ${ }^{120}$ A survey published in September by Nature found that among postdoctoral researchers, "nearly two-thirds believe that the pandemic has negatively affected their career prospects." ${ }^{121}$ With the challenges facing early career researchers, a bill was recently introduced in the House that, if passed, would aid in providing support to this cohort. 122

\section{Many institutions are adapting their tenure and promotion processes to account for some of these impacts. Due to the unprecedented impact of COVID-19, some institutions, including the University of Washington, Ohio State University, Penn State, and Florida State University (FSU), have paused the tenure and promotion clock for a year. ${ }^{123}$}

\footnotetext{
Performance Evaluations," Healthy Brown, March 23, 2020, https://healthy.brown.edu/updates/changes-hiring-and-performanceevaluations).

${ }^{120}$ Wudan Yan, "Early-Career Scientists at Critical Career Junctures Brace for Impact of COVID-19," Science, April 7, 2020, https://doi.org/10.1126/science.caredit.abc1291.

${ }^{121}$ Chris Woolston, “Pandemic Darkens Postdocs' Work and Career Hopes," Nature, Work, 585 (September 8, 2020): 309-12, https://doi.org/10.1038/d41586-020-02548-2.
}

${ }^{122}$ Representative Eddie Bernice Johnson and Representative Frank Lucas, "H.R.8044 - Supporting Early-Career Researchers Act," Pub. L. No. H.R.8044 (2020), https://www.congress.gov/bill/116th-congress/house-bill/8044/text. This bill was introduced to the House on August 14, 2020. The purpose of it is "to forestall the loss of research talent by establishing a temporary early career research fellowship program." If this bill were to pass and become a law the following provisions would be set in place: (1) the bill would permit the NSF to "establish a 2-year pilot program to award grants to highly qualified early-career investigators to carry out an independent research program at the institution of higher education chosen by such investigator, to last for a period not greater than 2 years" and (2) the bill recommends that Congress allocate \$250 million for said program in both fiscal year 2021 and 2022. (American Institute of Physics, "Supporting Early-Career Researchers Act - H.R.8044," American Institute of Physics (AIP), August 14, 2020, https://www.aip.org/fyi/federal-science-bill-tracker/116th/supporting-early-career-researchers-act). "Without supplemental funding from Congress for relief, federal research agencies will be forced to choose between abandoning new research opportunities of national importance or discontinuing research projects that are not yet completed, thus failing to maximize the return on federal dollars already invested" (Adria Schwarber, "Universities Make Case for Pandemic Relief Funds," American Institute of Physics (AIP), September 18, 2020, https://www.aip.org/fyi/2020/universities-make-case-pandemic-relief-funds).

${ }^{123}$ Some institutions have given junior faculty tenure clock extensions (Katie Langin, "The Pandemic Is Hitting Scientist Parents Hard, and Some Solutions May Backfire," Science, July 31, 2020, https://doi.org/10.1126/science.caredit.abe1220.) while many other institutions are offering tenure clock stoppages (Colleen Flaherty, "Faculty Home Work," Inside Higher Ed, March 24, 2020, https://www.insidehighered.com/news/2020/03/24/working-home-during-covid-19-proves-challenging-faculty-members) to help mitigate junior faculty members' grave concerns about losing months of writing and research due to virus related disruptions across the country. But will that be enough? The question remains to be answered. If we as a country and society get lucky and the global pandemic ends quickly — which unfortunately it does not look like it will—we will most likely still see a dip in the progress towards equality in scientific research. For examples of universities pausing their tenure track for faculty see the following: Ohio State University, "Tenure-Track Faculty: Extension of Tenure Clock Due to COVID-19," The Ohio State University Office of Academic Affairs, March 19, 2020, https://oaa.osu.edu/tenure-track-faculty-extension-tenure-clock-due-covid-19.; Michigan State University, "Extending The Reappointment/Promotion/Tenure Review Timeline," Human Resources Administrators \& Supervisors, 2020, https://hr.msu.edu/ua/promotion/faculty-academic-staff/coronavirus-tenure-clock-faqs.html.; University of Washington, "Promotion/Tenure Clock Extensions Due to COVID-19 - Faculty," University of Washington Office of Academic Personnel, 2020, https://ap.washington.edu/ahr/working/promotion-and-tenure-extensions/extension-of-promotion-tenure-clock-due-to-covid-19/.; West Virginia University, "COVID-19 Revised Annual Evaluation Guidelines," West Virginia University WVU Faculty, 2020, https://faculty.wvu.edu/policies-and-procedures/academic-freedom-professional-responsibility-promotion-and-tenure/facultyevaluation-promotion-and-tenure-guidelines/covid-19-revised-annual-evaluation-guidelines.; Penn State University, "Revisions to the 
WHAT WE DON'T KNOW: Will universities be able to invest in early career researchers or will there be a talent implosion?

\section{Gender Disparities}

There remains a stark gender disparity within academic science and research. ${ }^{24}$ And while gains have been made, "for female scientists, the pandemic also poses a significant threat to hard-won gender-equity gains achieved over the past few decades." 125 COVID-19 has caused additional challenges for researchers with caregiver and child care responsibilities-most markedly on mothers. This has yielded widespread coverage of significant drops in scholarly production and publishing by female researchers. ${ }^{126}$

\section{There remains a stark gender disparity within academic science
and research.}

Studies have confirmed the pattern. One survey published in the early summer found a substantial decline in time devoted to research among female scientists and those with young children. ${ }^{127}$ Another study, published in September, found that "the gender gap in medRxiv increased from 23\% in J anuary 2020 to 55\% in April 2020." The authors of this study highlighted that this finding, along with previous research, provides more evidence that women

\footnotetext{
Promotion and Tenure Administrative Guidelines and Frequently Asked Questions (FAQs) for Policy AC23 for 2020 - 2021 " (Penn State University, 2020), https://www.ist.psu.edu/sites/default/files/faculty-affairs/AC23-guideline-revisions.pdf.

124 Jevin D. West et al., "The Role of Gender in Scholarly Authorship," PLOS ONE 8, no. 7 e66212 (July 22, 2013): 1-6, https://doi.org/10.1371/journal.pone.0066212.; Corinne A. Moss-Racusin et al., "Science Faculty's Subtle Gender Biases Favor Male Students," ed. Shirley Tilghman, Proceedings of The National Science Academy of Sciences of the United States of America 109, no. 41 (October 9, 2012): 16474-79, https://doi.org/10.1073/pnas.1211286109.

${ }^{125}$ Virginia Gewin, "The Career Cost of COVID-19 to Female Researchers, and How Science Should Respond," Nature, July 20, 2020, https://www.nature.com/articles/d41586-020-02183-x.

${ }^{126}$ Colleen Flaherty, "More Bad News on Women's Research Productivity," Inside Higher Ed, May 20, 2020, https://www.insidehighered.com/quicktakes/2020/05/20/more-bad-news-womens-research-productivity.; Colleen Flaherty, "No Room of One's Own," Inside Higher Ed, April 21, 2020, https://www.insidehighered.com/news/2020/04/21/early-journal-submissiondata-suggest-covid-19-tanking-womens-research-productivity; Giuliana Viglione, "Are Women Publishing Less During the Pandemic? Here's What the Data Say," Nature 581 (May 20, 2020): 365-66, https://doi.org/10.1038/d41586-020-01294-9.; Nicole Bentancourt, "What About Research? Scholarship and COVID-19," Ithaka S+R, July 8, 2020, https://sr.ithaka.org/blog/what-aboutresearch-scholarship-and-covid-19/; Olga Shurchkov, "Is COVID-19 Turning Back the Clock on Gender Equality in Academia?," Medium, April 23, 2020, https://medium.com/@olga.shurchkov/is-covid-19-turning-back-the-clock-on-gender-equality-in-academia70c00d6b8ba1; Megan Frederickson, "COVID-19's Gendered Impact on Academic Productivity," GitHub, May 11, 2020, https://github.com/drfreder/pandemic-pub-bias/blob/master/README.md; Alessandra Minello, "The Pandemic and the Female Academic," Nature, April 17, 2020, https://doi.org/10.1038/d41586-020-01135-9; Emily Perry, Kristin Tessmar-Raible, and Florian Raible, "Parents in Science," Genome Biology 19, no. 1 (October 29, 2018): 1-5, https://doi.org/10.1186/s13059-018-1549-3; Colleen Flaherty, "The Mom Penalty," Inside Higher Ed, June 6, 2013, https://www.insidehighered.com/news/2013/06/06/new-bookgender-family-and-academe-shows-how-kids-affect-careers-higher-education; Katie Langin, "The Pandemic Is Hitting Scientist Parents Hard, and Some Solutions May Backfire," Science, July 31, 2020, https://doi.org/10.1126/science.caredit.abe1220; 500 Women Scientists, "Scientist Mothers Face Extra Challenges in the Face of COVID-19," Scientific American, May 7, 2020, , https://blogs.scientificamerican.com/voices/scientist-mothers-face-extra-challenges-in-the-face-of-covid-19/.

${ }^{127}$ Kyle R. Myers et al., "Unequal Effects of the COVID-19 Pandemic on Scientists," Nature Human Behavior, July 15, 2020, 1-4, https://doi.org/10.1038/s41562-020-0921-y.
} 
in academia "perform a greater proportion of domestic work than men, including in dual academic career partnerships." 128

Given these challenges, some academics are asking for policies to help them ease the burden of caring for children and working and conducting research at home. ${ }^{129}$ And some observers have argued that more needs to be done to protect equality in this area while further ensuring that the gender equality gained throughout time does not regress. ${ }^{130}$

WHAT WE DON'T KNOW: How deep will these gendered impacts on female researchers go and how long will they persist? How much of a setback will this pandemic create for women in scientific research? How will individual universities and the broader STEM community combat this disproportionate effect on female scientists and researchers? How long will it take women to regain the standing that they had prior to the shutdown and pandemic?

\section{Graduate Students}

Graduate students are facing some of the similar challenges that faculty members are during the COVID-19 pandemic, but are receiving fewer assurances. In the spring of 2020 countless grad students watched their education modality change overnight, putting degree timelines in question. Furthermore, these students worry about losing the external and university funding

\footnotetext{
${ }^{128}$ Mackenzie R. Wehner, Yao Li, and Kevin T. Nead, "Comparison of the Proportions of Female and Male Corresponding Authors in Preprint Research Repositories Before and During the COVID-19 Pandemic," JAMA Network Open 3, no. 9:e2020335 (September 17, 2020): 1-4, https://doi.org/doi:10.1001/jamanetworkopen.2020.20335.

${ }^{129}$ At Stanford University a letter written by postdocs and faculty members sent to administrators in June 2020, highlighted how COVID-19 is widening the gap between men and women in academia and research (Justine Modica et al., "COVID-19 Is Widening The Gap Between Men and Women in Academia," The Stanford Daily, June 11, 2020, sec. Op-Eds, https://www.stanforddaily.com/2020/06/11/covid-19-is-widening-the-gap-between-men-and-women-in-academia/). Earlier in July, 2020, 500 Women Scientists released a policy statement directed at supervisors and administrators, calling for and recommending more flexible deadlines, contract extensions, and further workplace adjustments that could help women and parents (500 Women Scientists Policy Position, "Recommendations to Minimize Career Penalties for Parents in STEM Fields During the COVID-19 Pandemic," accessed August 3, 2020, https://static1.squarespace.com/static/582cce42bebafbfc47a82b04/t/5efe2d4db415005eed87f73a/1593716047550/Mom+Penalty+a nd+COVID+Factsheet.pdf). However, one such university seemed to not be willing to provide support and faced a large amount of backlash. Florida State University (FSU) announced that it would "prohibit its employees from taking care of their children while working remotely, calling it a necessary step toward returning to normal operation during the Coronavirus pandemic" (Paul Basken, "US Campus Reinstates Bar on Looking After Children While Working," Times Higher Education, July 1, 2020, https://www.timeshighereducation.com/news/us-campus-reinstates-bar-looking-after-children-while-working.) This plan attracted a large amount of attention on social media not only from academics and researchers at FSU, but others in the community as well who regarded the requirement unreasonable and largely to have the biggest impact on women. This led to FSU to appear to walk back the announcement stating "we want to be clear - our policy does allow employees to work from home while caring for children" ("Remote Work Update," Florida State University News, July 2, 2020, https://news.fsu.edu/announcements/covid19/2020/07/02/remote-work-update/). The move by FSU was an attempt to try and reinstate a policy that once existed, but prior to the outbreak of the global pandemic. The idea that employees and researchers, especially women, would suddenly be required to make other arrangements for their children at home even as they had to continue working from home led to immediate and harsh backlash (Jacey Fortin and Derrick Bryson Taylor, "Florida State University Child Care Policy Draws Backlash," The New York Times, July 2, 2020, Ihttps://www.nytimes.com/2020/07/02/us/fsu-telecommute-remote.html?searchResultPosition=3.)

130 Jessica L. Malisch et al., "Opinion: In the Wake of COVID-19, Academia Needs New Solutions to Ensure Gender Equity," Proceedings of the National Science Academy of Sciences of the United States of America 117, no. 27 (July 7, 2020): 15378-81, https://doi.org/10.1073/pnas.2010636117.
} 
that supports their research. Prospective graduate students are experiencing major disruptions to the entrance exams, ${ }^{131}$ application, and admission process. ${ }^{132}$

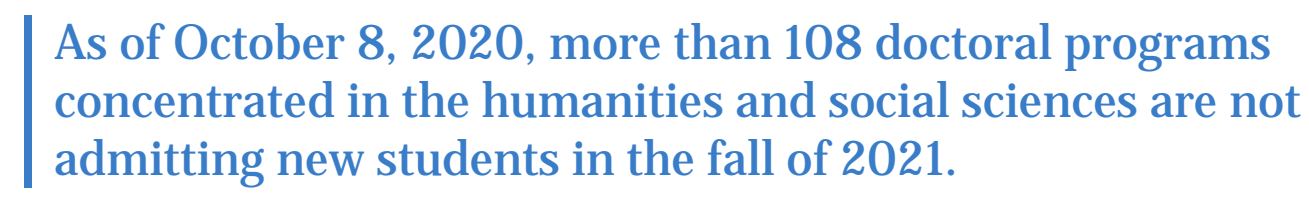

Graduate student cohorts are shrinking in some fields as universities put school-funded Ph.D. programs on pause due to the fiscal constraints for 2021-2022. As of October 8, 2020, more than 108 doctoral programs concentrated in the humanities and social sciences are not admitting new students in the fall of 2021. ${ }^{133}$ The reasoning behind all of these pauses is to ensure that there is enough funding for current school-funded Ph.D. students.

From the literature available, it does not seem that Ph.D. programs in the natural, life, and biological sciences are pausing admissions for the fall of 2021. ${ }^{134}$ Their doctoral students are typically supported by external research grants.

There may nevertheless be selected financial impacts for STEM graduate students. Some are dependent on teaching assistantships for their stipends, but teaching assistance for lab courses at many universities changed in spring 2020 due to the shutdown.

Of course, doctoral students are facing delays from disruptions to laboratory and field research, which may slow their degree progress. Some may no longer be on track to graduate within the time frame that external or university funding typically covers. These students may need extensions to their degrees, and possibly to their grant funding, in order to complete their dissertations. ${ }^{135}$ Advisors and administrators have struggled to balance compassion with

\footnotetext{
${ }^{131}$ As mentioned, the global pandemic is not only affecting those currently in graduate school, but also those who aspire to be in or are applying to grad school during this time. In-person graduate school entrance exams have been halted and the method of delivery has been changed to taking all qualifying exams at home and online. "The GRE General Test at home is now available everywhere that the computer-delivered GRE General Test is offered - at home administrations are currently available around the clock, seven days a week through September 30, 2020" (ETS GRE, "GRE General Test at Home," ETS GRE, 2020, https://www.ets.org/s/cv/gre/at-home/).

${ }^{132}$ For example, in-person information sessions about graduate programs were cancelled along with all campus and sometimes lab tours (James Urton, "UW Guidelines Helping to Ramp Up Research Safely During COVID-19," UW News, June 4, 2020, https://www.washington.edu/news/2020/06/04/research-ramp-up-covid-19/. In light of the enormous amount of disruptions that COVID-19 caused for graduate students during the application cycle for the 2020-2021 academic year, some institutions, such as The University of Alabama at Birmingham extended fall application deadlines for graduate programs ("Graduate School COVID-19 Updates," University of Alabama at Birmingham, 2020, https://www.uab.edu/graduate/about/graduate-school-covid-19-updates).

${ }^{133}$ Megan Zahneis, "More Doctoral Programs Suspend Admissions. That Could Have Lasting Effects on Graduate Education," The Chronicle of Higher Education, September 28, 2020, https://www.chronicle.com/article/more-doctoral-programs-suspendadmissions-that-could-have-lasting-effects-on-graduate-education.

${ }^{134}$ In fact, only one day after an announcement from the University of Pennsylvania, the chemistry department announced that they would actually continue to accept new Ph.D. students: Ashley Ahn, "Chemistry Department Will Not Pause Admissions for Ph.D. Students Next Academic Year," The Daily Pennsylvanian, September 16, 2020, https://www.thedp.com/article/2020/09/phdchemistry-penn-admissions-covid.

${ }^{135}$ Graduate students have similar concerns to faculty about how their research, and education, has been upended, but they are further apprehensive as to how all of these disruptions will impact their progress towards their degrees--"Yet accommodations to their program timelines and funding packages are almost nil" (Colleen Flaherty, "What About Graduate Students?" Inside Higher Ed,
} 
continuing high expectations. Victor DiRita, Professor and Chair in the Department of Microbiology and Molecular Genetics at Michigan State University said, "we don't want to water down what we accept as a completed thesis, but on the other hand, we want to be sensitive about students needing to get on with the next phase of their training (and lives)."136

In J uly, the National Opinion Research Center launched an NSF-funded study to help identify the needs and challenges of graduate students, specifically those in the STEM fields. ${ }^{137}$

WHAT WE DON'T KNOW: How many graduate students were unable to advance their research due to the pandemic and associated shutdowns? How will degree completion timelines be affected? Will sufficient funding be available to enable project completion? What are the longer-term impacts of the admissions pauses for Ph.D. programs and will natural and biological science programs begin to be affected?

\section{International Students}

International science and engineering graduate students make up more than one third of the total US graduate enrollment in science and engineering. ${ }^{138}$ While all students are facing issues with research due to pandemic-related shutdowns, international graduate students and postdocs are facing a very unique set of challenges. Tobin Smith, the vice president for policy at the AAU, says that "the international students and the role they play in support for STEM fields is of great concern. They are a significant part of the STEM workforce."139 The biggest concerns for international students and researchers revolve around the ability for them to continue joining the US academic research community. The global pandemic's travel disruptions coupled with immigration and visa-related challenges may result in fewer international students and researchers coming to the United States.

\footnotetext{
April 7, https://www.insidehighered.com/news/2020/04/07/graduate-students-seek-time-degree-and-funding-extensions-duringcovid-19. ) One graduate student at the University of Wisconsin at Madison stated that "responses by some administrators to graduate students' appeals for more funding or deadline extensions illustrates a systemic inequity that has dogged grad students for decades" (Megan Zahneis, "For Many Graduate Students, COVID-19 Pandemic Highlights Inequities," The Chronicle of Higher Education, March 26, 2020, https://www.chronicle.com/article/for-many-graduate-students-covid-19-pandemic-highlights-inequities/). In contrast, some institutions, such as UC Berkeley, have created web pages to address academic progress, extensions for projects and degrees, and accommodations regarding graduate student degree progress, but it does not seem that all universities are following suit ("COVID-19 Information for Graduate Students," Berkeley Graduate Division, August 1, 2020, https://grad.berkeley.edu/covid-19-information-for-graduate-students/).

${ }^{136}$ Aleksandra Sikora, Michael Ibba, and Victor DiRita, "Mentoring Graduate Students During \& Beyond COVID-19," American Society for Microbiology, May 6, 2020, https://asm.org/Articles/2020/May/Mentoring-Graduate-Students-During-Beyond-COVID-19.

137 "NORC at the University of Chicago to Conduct Study on Graduate Programs Coping with the COVID-19 Pandemic," NORC at the University of Chicago, July 1, 2020, https://www.norc.org/NewsEventsPublications/PressReleases/Pages/norc-at-the-universityof-chicago-to-conduct-study-on-graduate-programs-coping-with-the-covid-19-pandemic.aspx.

${ }_{138}$ National Science Board, "Science and Engineering Indicators 2018," National Science Board, January 2018, https://nsf.gov/statistics/2018/nsb20181/report/sections/higher-education-in-science-and-engineering/graduate-educationenrollment-and-degrees-in-the-united-states.

${ }^{139}$ Abby Olena, "The Pandemic's Effects on Recruiting International STEM Trainees," The Scientist, April 9, 2020, sec. News \& Opinion, https://www.the-scientist.com/news-opinion/the-pandemics-effects-on-recruiting-international-stem-trainees-67495.
} 


\title{
International science and engineering graduate students make up more than one third of the total US graduate enrollment in science and engineering.
}

\begin{abstract}
Visa issues ran the gamut in the spring, from extensions allowing students to take online classes, 140 to announcements that would have barred many international students from continuing their education and research in the US. ${ }^{141}$ On September 25, 2020, the Trump administration published a new proposed rule ${ }^{142}$ that if passed would create set fixed terms of up to four years for student visas as well as establishing procedures for visa extensions. ${ }^{143}$ The rule would also limit the initial visa period for certain categories of students to only two years solely based on their country of origin. ${ }^{144}$ The length of a typical Ph.D. program is typically
\end{abstract}

\footnotetext{
140 "Broadcast Message: Coronavirus Disease 2019 (COVID-19) and Potential Procedural Adaptations for F and M Nonimmigrant Students," Broadcast Message, Immigration and Customs Enforcement, March 9, 2020, https://www.ice.gov/doclib/sevis/pdf/bcm2003-01.pdf.

141 Jyoti Madhusoodanan, “'Disturbing and Cruel.' Universities Blast New Visa Rule for International Students," Science, July 8, 2020, https://doi.org/10.1126/science.caredit.abd7322.

142 U.S. Immigration and Customs Enforcement, Department of Homeland Security, "Establishing a Fixed Time Period of Admission and an Extension For Stay Procedure for Nonimmigrant Academic Students, Exchange Visitors, and Representatives of Foreign Information Media," Federal Register, 8 CFR, 85, no. 187 (September 25, 2020): 60526-98, https://www.govinfo.gov/content/pkg/FR-2020-09-25/pdf/2020-20845.pdf.

${ }^{143}$ If this rule was passed, "would only extend the stay beyond the prior admission date (typically the program end date for which the student was admitted to the United States as a F-1 nonimmigrant or was granted based on a change of status or extension of stay) of an otherwise eligible F-1 student requesting additional time to complete their program if the additional time needed is due to a compelling academic reason, documented medical illness or medical condition, or circumstance that was beyond the student's control" (U.S. Immigration and Customs Enforcement, Department of Homeland Security, "Establishing a Fixed Time Period of Admission and an Extension For Stay Procedure for Nonimmigrant Academic Students, Exchange Visitors, and Representatives of Foreign Information Media," Federal Register, 8 CFR, 85, no. 187 (September 25, 2020): 60526-98, https://www.govinfo.gov/content/pkg/FR-2020-09-25/pdf/2020-20845.pdf).

${ }^{144}$ Specifically, "exchange visitors who were born in or are citizens of countries listed in the State Sponsor of Terrorism List" (U.S. Immigration and Customs Enforcement, Department of Homeland Security, "Establishing a Fixed Time Period of Admission and an Extension For Stay Procedure for Nonimmigrant Academic Students, Exchange Visitors, and Representatives of Foreign Information Media," Federal Register, 8 CFR, 85, no. 187 (September 25, 2020): 60526-98,

https://www.govinfo.gov/content/pkg/FR-2020-09-25/pdf/2020-20845.pdf). There are currently four countries designated as a statesponsor of terrorism: (1) North Korea, (2) Iran, (3) Sudan, and (4) Syria. Furthermore, this two-year visa limit, with the possibility of renewal, would apply to citizens of countries who have student and exchange visitor visa overstay rates that are greater than 10 percent. (For definition of "overstay" see pg. 7 of the following Homeland Security report: "Fiscal Year 2019 Entry/Exit Overstay Report," Report. U.S. Department of Homeland Security, March 30, 2020, https://www.dhs.gov/sites/default/files/publications/20 0513 fy19-entry-and-exit-overstay-report.pdf). According to the Homeland Security entry/exit overstay report there are 58 countries—mostly affecting students in Africa and parts of Asia—with visa overstay for international students and exchange visitors that are greater than 10 percent. They are the following: Afghanistan, Benin, Bhutan, Burkina Faso, Burma, Burundi, Cameroon, Cape Verde, Central African Republic, Chad, Congo-Brazzaville, CongoKinshasa, Côte d'Ivoire, Djibouti, Equatorial Guinea, Eritrea, Ethiopia, Gabon, the Gambia, Ghana, Guinea, Guinea-Bissau, Guyana, Haiti, Iraq, Kenya, Kosovo, Kyrgyzstan, Liberia, Libya, Malawi, Mauritania, Moldova, Mongolia, Nepal, Niger, Nigeria, Papua New Guinea, the Philippines, Rwanda, Samoa, Senegal, Sierra Leone, Somalia, South Sudan, Sudan, Syria, Tajikistan, Tanzania, Togo, Tonga, Turkmenistan, Tuvalu, Uganda, Uzbekistan, Vietnam, Yemen, and Zambia. For the full list of overstay rates for nonimmigrant students see pgs. 20-24 of the following Department of Homeland Security 2019 report: "Fiscal Year 2019 Entry/Exit Overstay Report," Report. U.S. Department of Homeland Security, March 30, 2020, https://www.dhs.gov/sites/default/files/publications/20 0513 fy19-entry-and-exit-overstay-report.pdf.
} 
longer than four years, so if this rule were to take effect, many international graduate students pursuing doctoral study would be forced to apply for an extension mid-program. ${ }^{145}$

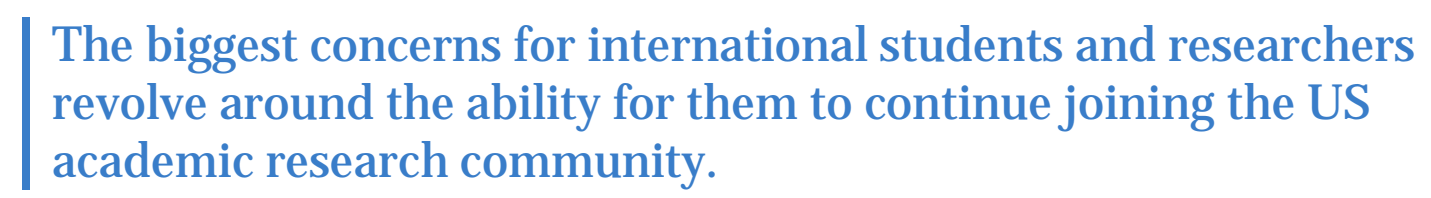

While these proposed visa changes are not directly the consequence of the pandemic, they are part of a growing sense that the US has become less hospitable to international students. Even if this specific rule is not implemented, there is a risk that the supply of the most competitive international graduate students will decline. This would be an important challenge to many universities' talent acquisition strategy, with potential implications to their ability to complete grant-funded research in certain fields.

WHAT WE DON'T KNOW: What will happen to the status of international students' visas throughout the academic year, especially to those students who have visas and are solely conducting research but not taking any courses? If the new visa rules are implemented, how will it alter the supply of research talent? How will universities fill the gap if they are unable to enroll international graduate students in the same numbers? How severely will the research enterprise be affected (financial impacts, production impacts, lab impacts, etc.) if it loses international students and researchers in great numbers?

\footnotetext{
${ }^{145}$ Elizabeth Redden, "Major Changes to Student Visa Rules Proposed," Inside Higher Ed, September 25, 2020, sec. News, Global, https://www.insidehighered.com/news/2020/09/25/trump-administration-proposes-major-overhaul-student-visa-rules.
} 


\section{Conclusion}

It is evident that the research enterprise within US colleges and universities has been through a great deal of trauma, disruption, and in some cases chaos these last seven months. Imperative questions have been answered over these months and the federal government research-funding agencies, such as the NIH and NSF, and institutions have been working tirelessly on this unprecedented and unforeseen situation since the global pandemic shook the research enterprise in early March of 2020. Currently, the immediate future of academic research is unknown. However, it is clear that without a COVID-19 vaccine the way that graduate students, postdocs, faculty, and staff conduct research in a university setting will differ from what we saw at the beginning of 2020. To maintain the strength and status quo of the US higher education research enterprise, research needs to remain steady, and in many cases may need to increase, regardless of a vaccine. We may now begin to see priorities differ as the government and universities are slashing budgets. These cuts will impact the hiring of research personnel and thereby could have the potential to slow down research activities at universities. Applied research will most likely become a priority for revenue generation. However, there are still a large number of questions that remain unanswered and simply unknown about the dynamics and impacts of COVID-19 on the research enterprise within US higher education and how long these effects will last. 